\title{
Genetic Diversity and Population Structure of Pythium irregulare from Soybean and Corn Production Fields in Ohio
}

J. Huzar-Novakowiski and A. E. Dorrance, ${ }^{\dagger}$ Department of Plant Pathology, The Ohio State University, Ohio Agricultural Research and Development Center, Wooster, OH 44691

\begin{abstract}
High levels of genetic diversity have been described within the Pythium irregulare complex from several host plants; however, little is known about the population structure in fields used for grain production. Therefore, the objective of this study was to evaluate the genetic diversity and population structure of 53 isolates baited from 28 soybean and corn production fields from 25 counties in Ohio. Genetic diversity was characterized based on sequence analysis of the internal transcribed spacer (ITS1-5.8S-ITS2) region and with 21 simple sequence repeat (SSR) markers. In addition, aggressiveness on soybean, optimum growth temperature, and sensitivity to metalaxyl fungicide were determined. ITS sequence analysis indicated that

four isolates clustered with $P$. cryptoirregulare, whereas the remaining isolates clustered with $P$. irregulare that was subdivided into two groups (1 and 2). Cluster analysis of SSR data revealed a similar subdivision, which was also supported by structure analysis. The isolates from group 2 grew at a slower rate, but both groups of $P$. irregulare and $P$. cryptoirregulare recovered in this study had the same optimum growth at $27^{\circ} \mathrm{C}$. Variability of aggressiveness and sensitivity toward metalaxyl fungicide was also observed among isolates within each group. The results from this study will help in the selection of isolates to be used in screening for resistance, assessment of fungicide efficacy, and disease management recommendations.
\end{abstract}

Seed and seedling disease of soybean (Glycine max [L.] Merr.) can be caused by several Pythium spp. leading to reduction in seed germination, stand, and yield. Typically, cool and moist conditions at the beginning of the growing season are conducive for infection and favor disease development (Martin and Loper 1999). Among all Pythium spp. that can infect soybean, Pythium irregulare Buisman is one of the most common and aggressive pathogens recovered from symptomatic plants in Ohio (Broders et al. 2007, 2009; Dorrance et al. 2004) and other regions in the United States (Jiang et al. 2012; Radmer et al. 2017; Rizvi and Yang 1996; Zitnick-Anderson and Nelson 2015).

$P$. irregulare is a homothallic oomycete with a diploid vegetative state that reproduces sexually with the formation of oospores or asexually with formation of sporangia and zoospores (van der Plaats-Niterink 1981). Based on phylogenetic studies of the internal transcribed spacer (ITS) region of the nuclear ribosomal DNA, $P$. irregulare is placed into clade $\mathrm{F}$, which also includes other important plant pathogens such as $P$. sylvaticum and $P$. spinosum (Lévesque and De Cock 2004). P. irregulare has been described as a cryptic species complex (Al-Sa'di et al. 2008; Garzón et al. 2005a, b) because it includes two or more phylogenetic species that cannot be distinguished based on morphological features (Milgroom 2015). Additionally, cryptic species of some fungi may differ in pathogenicity features

${ }^{\dagger}$ Corresponding author: A. E. Dorrance; E-mail: dorrance.1@osu.edu

Funding: Jaqueline Huzar-Novakowiski is a graduate student funded by Coordenação de Aperfeiçoamento de Pessoal de Nível Superior (CAPES) through the Science without Borders Program from Brazil. This project was also funded in part through check-off dollars provided by the Ohio Soybean Council, and funds appropriated to the Ohio Agricultural Research and Development Center, The Ohio State University, and the National Institute of Food and Agriculture, United States Department of Agriculture (USDA), Hatch project for Development of Disease Management Strategies for Soybean Pathogens in Ohio OHO01303.

The sequences reported in this study were deposited in the GenBank database (accession numbers: MF765683 to MF765735).

*The $\boldsymbol{e}$-Xtra logo stands for "electronic extra" and indicates that seven supplementary tables and four supplementary figures are published online.

Accepted for publication 11 April 2018.

(c) 2018 The American Phytopathological Society such as toxin production in Aspergillus flavus (Geiser et al. 2000) or host preference as in Ceratocystis fimbriata (Steimel et al. 2004). High levels of diversity within the $P$. irregulare complex have been reported based on biochemical (Barr et al. 1997), molecular (Garzón et al. 2005a; Matsumoto et al. 2000; Spies et al. 2011; Weiland et al. 2015), morphological (Barr et al. 1997; Matsumoto et al. 2000), and serological studies (White et al. 1994). Consequently, diagnostics and management of this important water mold could become more challenging.

The intraspecific variation of $P$. irregulare has been documented in several previous studies. Initially, Barr et al. (1997) separated a worldwide collection of 125 isolates into two groups (A and B) based on analysis of 11 isozyme loci. Matsumoto et al. (2000) used 47 isolates from different hosts and 17 geographic origins, mostly from Japan but also from other countries, for ITS-RFLP and RAPD analyses, and four groups were identified (I to IV). These same four groups were confirmed with phylogenetic analysis based solely on the ITS sequence by Lévesque and De Cock (2004). Later, Garzón et al. (2005b) identified genetic differentiation among 68 isolates from different hosts, mainly from ornamental plants in Pennsylvania but also from other regions around the world, that separated into two groups (IR-I and IR-II). The isolates from this same study were evaluated further, and a new species within the $P$. irregulare complex was characterized based on morphological features as well as variation in both the ITS region and cox II gene (Garzón et al. 2007).

In agricultural systems, genetic diversity and population structure of pathogens may be affected by location (Brewer and Milgroom 2010; Frenkel et al. 2012; Lamour and Hausbeck 2001), host range (Chowdappa et al. 2016; Frenkel et al. 2012; Harvey et al. 2000; Lin et al. 2015; Mammella et al. 2013; Peever et al. 1999), fungicide resistance (Konstantinou et al. 2015; Mohd-Assaad et al. 2016; Suzuki et al. 2010), and cultural practices such as crop or cultivar rotation (Leach et al. 2012; Stewart et al. 2014). Overall, soilborne pathogens are thought to have limited gene flow, and as a result, population structure over time tends to be affected by processes such as random genetic drift that leads to a reduction in genetic diversity (Harvey et al. 2000) and development of subpopulations. Although $P$. irregulare is homothallic, there is evidence of outcrossing (Harvey et al. 2000, 2001), which could result in recombinant genotypes and contribute to increased genetic diversity. This could impact soybean production by development of pathogen populations that are more prone to develop resistance to fungicide seed treatments as well as the ability to readily adapt to host resistance. A significant interaction between different soybean genotypes and isolates has been 
demonstrated for P. ultimum (Balk 2014), and it may also occur for other Pythium species. Therefore, understanding the genetic variation within $P$. irregulare may identify isolates that are more suitable for effective germplasm screening for resistance.

Population genetics combined with epidemiology can provide insights about the population biology of pathogens, which may contribute to the development of more effective disease management strategies (McDonald and Mundt 2016; Milgroom 2015). An important component of population genetic structure analysis is the estimation of genetic diversity (Grünwald et al. 2003), which can be performed at different scales such as number of alleles at a single locus, multilocus genotypes, or nucleotide sequences (Milgroom 2015). Sequence analysis of nuclear (Garzón et al. 2005a; Lévesque and De Cock 2004; Matsumoto et al. 2000; Spies et al. 2011; Villa et al. 2006) or mitochondrial (Garzón et al. 2005a; Martin 2000; Spies et al. 2011; Villa et al. 2006) DNA is a common technique used to assess genetic diversity. However, contrasting results have been obtained when comparing nuclear and mitochondrial phylogenies of isolates of P. irregulare (Spies et al. 2011), which may be due to different inheritance patterns and selective forces acting independently. Hence, the use of complementary methods is desirable to better characterize the genetic diversity within $P$. irregulare. In the past, restriction fragment length polymorphism (RFLP) (Harvey et al. 2001; Wang and White 1997), random amplified polymorphic DNA (RAPD) (Matsumoto et al. 2000), and amplified fragment length polymorphism (AFLP) (Al-Sa'di et al. 2008; Garzón et al. 2005a, b; Weiland et al. 2015) were widely used for population genetic studies of $P$. irregulare. More recently, the increased amount of sequence data available and use of next-generation sequencing at reduced costs (Fernandez-Silva et al. 2013; Santana et al. 2009; Schoebel et al. 2013) has accelerated the development and use of simple sequence repeat (SSR) markers (Lee and Moorman 2008; Stewart et al. 2016; Weiland et al. 2015) as well as single nucleotide polymorphisms (SNPs) for population genetic studies of other plant pathogens (Mammella et al. 2013; Milgroom et al. 2014, 2016; Talas and McDonald 2015).

In Ohio, soybean and corn are produced in several regions on heavy clay soils with a long history of occurrence of diseases caused by soilborne pathogens. Despite the widespread occurrence and damage caused by $P$. irregulare, little is known about the genetic diversity of this pathogen in Ohio. Due to the assumed limited gene flow of soilborne organisms and the potential effect of cultural practices on genetic diversity of plant pathogens, we hypothesized that the genetic structure of $P$. irregulare varies greatly among and within regions, counties, or even fields, which may have their own or several subpopulations as already reported for Phytophthora sojae, another homothallic oomycete (Stewart et al. 2016). Therefore, the characterization of the genetic diversity and population structure of $P$. irregulare, along with identification of factors associated with the detected variation, may be used to make inferences about evolutionary processes (Brewer and Milgroom 2010; Goss et al. 2009; Villa et al. 2006) as well as to provide insights into disease management (McDonald and Mundt 2016). Hence, the objective of this study was to assess and compare the population structure and genetic diversity of isolates of $P$. irregulare based on SSR markers as well as to characterize their aggressiveness, growth rate, and fungicide sensitivity. Isolates were baited from soil collected from soybean and corn fields from 25 production regions in Ohio. The same SSR markers previously developed by Lee and Moorman (2008) were used in this study. Ultimately, we aim to use this information primarily for selecting isolates for further use in germplasm screening for resistance and assessment of the efficacy of novel fungicides.

\section{Materials and Methods}

Origin of the isolates. Fifty-three isolates of $P$. irregulare from the Soybean Pathology Laboratory Oomycete Collection at the Ohio Agricultural Research and Development Center, Wooster, $\mathrm{OH}$, were used for this study (Table 1). Isolates were first obtained from a survey in 2004 and 2005 by baiting from soil with either soybean or corn seedlings (Broders et al. 2009; Dorrance et al. 2004), and stored at $15^{\circ} \mathrm{C}$ in slant vials (Wheaton, Millville, $\mathrm{NJ}$ ) containing $10 \mathrm{ml}$ of po-

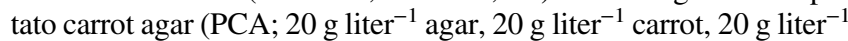
potato). Isolates were selected to represent two production regions, Northwest and Southwest, across the state of Ohio (Fig. 1) with history of seedling diseases and located in distinct soil regions (Broders et al. 2009).

DNA extraction. Four 5-mm plugs from a culture grown on PCA for 3 days were transferred to a 125-ml Erlenmeyer flask containing $50 \mathrm{ml}$ of sterile V8 broth ( $40 \mathrm{ml} \mathrm{V8} \mathrm{juice,} 0.6 \mathrm{~g} \mathrm{CaCO}_{3}, 0.2 \mathrm{~g}$ yeast extract, and $1 \mathrm{~g}$ sucrose per liter), and were incubated at approximately 23 to $26^{\circ} \mathrm{C}$ in the dark for 7 days. Mycelia were collected through vacuum aspiration through a P5 Whatman filter paper (Fisher Scientific, Pittsburg, PA). Mycelia were transferred to a cold sterile mortar, frozen with liquid nitrogen, ground with a cold sterile pestle, placed in a 2-ml microcentrifuge tube, and stored at $-20^{\circ} \mathrm{C}$. DNA was extracted following the protocol described by ZelayaMolina et al. (2011). DNA quality was assessed on agarose gel (1\% $\mathrm{w} / \mathrm{v}$ ) electrophoresis, and by measuring the absorbance at ratio 260/ 280 using a NanoDrop ND-1000 Spectrophotometer (ThermoFisher Scientific, Wilmington, DE). DNA concentration was adjusted to

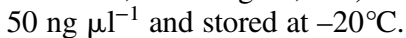

ITS sequence analysis. The ITS1-5.8S-ITS2 sequences were obtained by using the universal primers ITS1 ( $5^{\prime}$-TCCGTAGGTGA ACCTGCGG-3') and ITS4 (5'-TCCTCCGCTTATTGATATGC-3') (White et al. 1990). The polymerase chain reaction (PCR) reaction mix, adapted from the Promega Protocol GoTaq Flexi DNA polymerase (Promega Corp., Madison, WI), contained $1 \times$ GoTaq reaction buffer, $1.63 \mathrm{mM} \mathrm{MgCl} 2,0.43 \mathrm{mM}$ dNTPs, $0.25 \mu \mathrm{l}$ of Taq polymerase, $0.22 \mu \mathrm{M}$ of each primer (ITS1 and ITS4), and $1 \mu$ l of DNA template $\left(50 \mathrm{ng} \mu \mathrm{l}^{-1}\right)$ in $25 \mu \mathrm{l}$ reactions. The PCR parameters for amplification were the same as those in Moorman et al. (2002): $94^{\circ} \mathrm{C}$ for $5 \mathrm{~min}, 34$ cycles of $94^{\circ} \mathrm{C}$ for $1 \mathrm{~min}, 53^{\circ} \mathrm{C}$ for $1 \mathrm{~min}$, and $72^{\circ} \mathrm{C}$ for $1 \mathrm{~min}$, a final extension at $72^{\circ} \mathrm{C}$ for $5 \mathrm{~min}$, and hold at $4^{\circ} \mathrm{C}$. The PCR amplicons of the correct size were confirmed by gel electrophoresis and were then submitted to the Molecular and Cellular Imaging Center at the Ohio Agricultural Research and Development Center (MCIC, Wooster, OH) for Sanger sequencing by capillary electrophoresis using ABI Prism 3100xl genetic analyzer with 3'-BigDye labeling chemistry. Sequence quality was checked with CodonCode Aligner (CodonCode Corporation, Centerville, MA) and ends with low quality were removed. The complimentary reverse sequence was obtained and sequences from the forward and reverse primers were aligned with CodonCode Aligner and sequence was assessed for alignment errors. Sequence data were compared with voucher sequences deposited in the National Center for Biotechnology Information (NCBI) using the Basic Local Alignment Search Tool (BLAST; https://blast.ncbi.nlm.nih. gov/Blast.cgi) to verify the identity of each isolate.

The ITS sequences were aligned with ClustalW (Thompson et al. 1994) and manually edited for alignment errors in MEGA version 7.0.25 (Kumar et al. 2016). UPGMA algorithm was used to estimate the phylogenetic tree. Bootstrap analysis was performed with 1,000 replications to estimate branch support. The ITS sequences obtained from this study were compared with sequences deposited in NCBI (Supplementary Table S1) including the neotype strain of $P$. irregulare in clade F from Lévesque and De Cock (2004); five sequences of $P$. irregulare s.s. (sensu stricto); three sequences of $P$. cryptoirregulare from Garzón et al. (2007); and two sequences from Matsumoto et al. (2000) representing groups I and II. Even though Matsumoto et al. (2000) described four groups of $P$. irregulare, sequences from group III and IV are closely related to $P$. sylvaticum (Garzón et al. 2007), and since none of the sequences from this study matched isolates from these groups, they were not included in our final analysis. A sequence of $P$. spinosum from clade F (Lévesque and De Cock 2004) was included as outgroup.

SSR analysis. Simple sequence repeat (SSR) markers were used to evaluate genetic diversity among the $P$. irregulare isolates. Twenty-one primer sets previously identified and characterized by Lee and Moorman (2008) were used in this study. The PCR reaction mix contained $1 \times$ Green GoTaq reaction buffer, $1.63 \mathrm{mM} \mathrm{MgCl}_{2}$, 
$0.43 \mathrm{mM}$ dNTPs, $0.25 \mu \mathrm{l}$ of Taq polymerase, $0.26 \mu \mathrm{M}$ of each primer, and $1 \mu \mathrm{l}$ of DNA template $\left(50 \mathrm{ng}^{\mathrm{l}} \mathrm{l}^{-1}\right)$ in $23 \mu \mathrm{l}$ reactions. PCR amplification was performed as follows: $94^{\circ} \mathrm{C}$ for $2 \mathrm{~min}, 35 \mathrm{cy}-$ cles of $94^{\circ} \mathrm{C}$ for $30 \mathrm{~s}$, annealing temperatures ranged from 55 to $60^{\circ} \mathrm{C}$ depending on primer set for $30 \mathrm{~s}$, extension at $72^{\circ} \mathrm{C}$ for $30 \mathrm{~s}$, final extension at $72{ }^{\circ} \mathrm{C}$ for $10 \mathrm{~min}$, and hold at $4{ }^{\circ} \mathrm{C}$. A $5-\mu l$ aliquot of the PCR product was loaded into a well of a $4 \%$ high density agarose (Amresco, Solon, OH) gel pre-stained with GelRed (Biotium Inc.,
Fremont, CA), and electrophoresis was carried out at $95 \mathrm{v}$ for $6 \mathrm{~h}$. In each gel, multiple wells were loaded with 100 and 20 bp DNA ladders (O'Range Ruler, ThermoScientific, Waltham, MA). Bands were visualized under UV light using an imaging system (Gel Logic 112, Carestream, Woodbridge, CT). Alleles at each locus were scored based on the size of PCR products compared with the ladders. Different band sizes were considered as different alleles. Since $P$. irregulare is a diploid organism (van der Plaats-Niterink 1981), one allele

Table 1. Isolates of Pythium irregulare complex recovered ${ }^{a}$ from soybean and corn production fields in Ohio used in this study

\begin{tabular}{|c|c|c|c|c|c|c|c|}
\hline Isolate & Region & County & Soil type & Host & $\mathbf{M L G}^{\mathbf{b}}$ & SSR group ${ }^{c}$ & Accession number ${ }^{d}$ \\
\hline Ash-1-1-7 & Northwest & Ashland & Loam & Soybean & 1 & 1 & MF765683 \\
\hline Ash-1-4-14 & Northwest & Ashland & Loam & Corn & 36 & 1 & MF765684 \\
\hline Ash-1-6-3 & Northwest & Ashland & Loam & Soybean & 37 & 1 & MF765685 \\
\hline Ash-2-1-12 & Northwest & Ashland & HiSilt & Soybean & 5 & 1 & MF765686 \\
\hline Ash-2-2-10 & Northwest & Ashland & HiSilt & Soybean & 22 & 2 & MF765687 \\
\hline Ash-2-4-2 & Northwest & Ashland & HiSilt & Soybean & 43 & 1 & MF765688 \\
\hline Ash-2-6-2 & Northwest & Ashland & HiSilt & Soybean & 6 & 1 & MF765689 \\
\hline Br-2-3-4 & Southwest & Brown & Clay loam & Soybean & 48 & 1 & MF765690 \\
\hline $\mathrm{Br}-2-3-5$ & Southwest & Brown & Clay loam & Soybean & 49 & 1 & MF765691 \\
\hline Br-2-5-14 & Southwest & Brown & Clay loam & Corn & 3 & 1 & MF765692 \\
\hline Br-2-6-4 & Southwest & Brown & Clay loam & Soybean & 46 & 1 & MF765693 \\
\hline Cham-2-1-3 & Southwest & Champaign & Clay loam & Soybean & ND & 3 & MF765732 \\
\hline Clark-1-4-13 & Southwest & Clark & Clay loam & Corn & 14 & 2 & MF765694 \\
\hline Clark-1-5-3 & Southwest & Clark & Clay loam & Soybean & 13 & 2 & MF765695 \\
\hline Cler-1-1-12 & Southwest & Clermont & HiSilt & Soybean & 44 & 1 & MF765696 \\
\hline Cler-1-4-1 & Southwest & Clermont & HiSilt & Soybean & 47 & 1 & MF765697 \\
\hline Cler-2-1-10 & Southwest & Clermont & Loam & Soybean & 26 & 2 & MF765698 \\
\hline Craw-1-1-10 & Northwest & Crawford & Clay loam & Soybean & ND & 3 & MF765733 \\
\hline Darke-3-1-8 & Southwest & Darke & HiSilt & Soybean & 15 & 2 & MF765699 \\
\hline Darke-3-2-14 & Southwest & Darke & HiSilt & Soybean & 21 & 2 & MF765700 \\
\hline Darke-4-3-22 & Southwest & Darke & HiSilt & Corn & 20 & 2 & MF765701 \\
\hline Def-2-2-6 & Northwest & Defiance & HiSand & Soybean & 12 & 2 & MF765702 \\
\hline Def-2-4-14 & Northwest & Defiance & HiSand & Soybean & 19 & 2 & MF765703 \\
\hline Def-2-5-22 & Northwest & Defiance & HiSand & Corn & 4 & 1 & MF765704 \\
\hline Erie-2-6-4 & Northwest & Erie & Clay loam & Soybean & ND & 3 & MF765734 \\
\hline Fay-2-3-2 & Southwest & Fayette & Clay loam & Soybean & 18 & 2 & MF765705 \\
\hline Ful-2-6-4 & Northwest & Fulton & HiSand & Soybean & 9 & 1 & MF765706 \\
\hline Gr-1-5-1 & Southwest & Green & Clay loam & Soybean & 11 & 2 & MF765707 \\
\hline Gr-2-3-3 & Southwest & Green & Clay loam & Corn & 29 & 2 & MF765708 \\
\hline Hen 1-4-3 & Northwest & Henry & Loam & Soybean & 17 & 2 & MF765709 \\
\hline Hen-1-6-4 & Northwest & Henry & Loam & Soybean & 41 & 2 & MF765710 \\
\hline Hen-1-1-9 & Northwest & Henry & Loam & Soybean & 30 & 1 & MF765711 \\
\hline High-2-5-8 & Southwest & High & Clay loam & Soybean & 25 & 2 & MF765712 \\
\hline Hur-1-4-11 & Northwest & Huron & Loam & Soybean & 42 & 1 & MF765713 \\
\hline Logan-1-3-10 & Southwest & Logan & Clay loam & Soybean & 39 & 1 & MF765714 \\
\hline Lucas-2-1-1 & Northwest & Lucas & Loam & Soybean & 23 & 2 & MF765715 \\
\hline Mad-2-1-4 & Southwest & Madison & Clay loam & Soybean & 31 & 2 & MF765716 \\
\hline Mad-2-2-1 & Southwest & Madison & Clay loam & Soybean & 32 & 2 & MF765717 \\
\hline Mad-2-5-4 & Southwest & Madison & Clay loam & Soybean & 24 & 2 & MF765718 \\
\hline Miami-1-3-13 & Southwest & Miami & Clay & Corn & 33 & 2 & MF765719 \\
\hline Mont-1-1-2 & Southwest & Montgomery & Clay loam & Soybean & 34 & 2 & MF765720 \\
\hline Mont-1-4-7 & Southwest & Montgomery & Clay loam & Soybean & 35 & 2 & MF765721 \\
\hline Mor-2-1-16 & Northwest & Morgan & Clay loam & Corn & 2 & 1 & MF765722 \\
\hline Mor-2-3-15 & Northwest & Morgan & Clay loam & Corn & 7 & 1 & MF765723 \\
\hline Mor-2-4-8 & Northwest & Morgan & Clay loam & Soybean & 10 & 1 & MF765724 \\
\hline Mor-2-5-9 & Northwest & Morgan & Clay loam & Soybean & 8 & 1 & MF765725 \\
\hline Pick-1-6-16 & Southwest & Pickaway & Clay loam & Corn & 16 & 2 & MF765726 \\
\hline Sand-1-4-25 & Northwest & Sandusky & HiSand & Corn & 38 & 1 & MF765727 \\
\hline Sand-1-6-22 & Northwest & Sandusky & HiSand & Corn & 40 & 1 & MF765728 \\
\hline War-1-1-1 & Southwest & Warren & Clay loam & Soybean & 27 & 2 & MF765729 \\
\hline War-1-6-3 & Southwest & Warren & Clay loam & Soybean & 45 & 1 & MF765730 \\
\hline Wood-1-4-13 & Northwest & Wood & Clay loam & Corn & ND & 3 & MF765735 \\
\hline Wood-1-6-9 & Northwest & Wood & Clay loam & Soybean & 28 & 2 & MF765731 \\
\hline
\end{tabular}

a Isolation was performed by baiting from soil with soybean or corn seedlings in 2004 and 2005 (Broders et al. 2007).

${ }^{b}$ Multilocus genotype (MLG) based on 21 simple sequence repeat (SSR) markers. ND = MLG was not determined for this isolate because it clustered with P. cryptoirregulare.

${ }^{\mathrm{c}}$ SSR group determined based on analysis of simple sequence repeat genetic markers. Group 1 and group 2 correspond to isolates of $P$. irregulare and group 3 corresponds to isolates of $P$. cryptoirregulare.

${ }^{\mathrm{d}}$ GenBank identification number for the internal transcribed spacer (ITS1-5.8S-ITS2) sequence. 
per locus represented a homozygous condition while two alleles per locus were heterozygous. Absence of a band was treated as missing data.

Analysis was focused on region level considering two populations, Northwest and Southwest (Fig. 1). Allelic diversity, number of absolute alleles per locus $\left(N_{a}\right)$, number of effective alleles $\left(N_{e}\right)$, observed heterozygosity $\left(H_{o}\right)$, expected heterozygosity $\left(H_{e}\right)$, Hardy-Weinberg equilibrium (HWE), fixation index $\left(\mathrm{F}_{\mathrm{ST}}\right)$, Shannon's information index $(I)$, and gene flow $\left(\mathrm{N}_{\mathrm{m}}\right)$ among populations were determined for each locus with GenAlEx version 6.5 (Peakall and Smouse 2012). Moreover, genetic distances were calculated, a principal coordinate analysis (PCoA) was completed, and an analysis of molecular variance (AMOVA) was performed with 999 permutations. Genetic distances, calculated by Bruvo's genetic distance method (Bruvo et al. 2004), were used to generate a dendrogram using UPGMA algorithm with bootstrap support based on 1,000 replications. All of these analyses were performed with poppr $\mathrm{R}$ package version 2.4.1 (Kamvar et al. 2014) in $\mathrm{R}$ version 3.4.0.

Population structure was also analyzed with a Bayesian approach using STRUCTURE 2.3.4 (Hubisz et al. 2009; Pritchard et al. 2000). Parameters were set to 50,000 replications as burn-in and 150,000 replications for the Markov-Chain Monte Carlo method (Rodriguez-Bonilla et al. 2014). The most likely number of populations $(\mathrm{K})$ was determined by the delta $\mathrm{K}(\Delta \mathrm{K})$ method (Evanno et al. 2005) with STRUCTURE HARVESTER Web v.0.6.94 (Earl and vonHoldt 2012).
Mycelial growth rate and optimum growth temperature. All isolates were grown on PCA for 3 days. A 5-mm diameter mycelial plug taken from the edge of the growing colony was transferred to a $100 \times 15 \mathrm{~mm}$ Petri dish containing $15 \mathrm{ml}$ of PCA media. Cultures were incubated in the dark at 12, 15, 18, 21, 24, 27, 30, 33, and $36^{\circ} \mathrm{C}$ for $24 \mathrm{~h}$. Mycelial growth was determined by measuring the diameter of the colony with a ruler. The experiment was carried out in a split-plot design with temperature as main plot and isolates as subplots. There were three replicated plates for each isolate $\times$ temperature combination, and the experiment was completed twice. Data analyses were performed with PROC MIXED using SAS 9.4 (SAS Inc., Cary, NC). Initially, a group number was assigned to each isolate based on ITS sequence and SSR data analyses. Then, for statistical analysis, isolate group and temperature were considered as fixed factors, while experiment and interaction of temperature and experiment were considered as random factors. Least square means (lsmeans) statements was used to estimate the expected value (means) for the main effects and interaction, and contrast statements were used to compare the main and simple effect means for all significant effects and interactions. The temperature that allowed the highest rate of growth was considered as the optimal temperature for each group and each isolate within groups.

Isolate aggressiveness in seed plate assay. Isolates were grown for 3 days in $60 \times 15 \mathrm{~mm}$ Petri dishes containing PCA media and aggressiveness was evaluated with a seed plate assay following the methodology described by Broders et al. (2007). A 5-mm mycelial

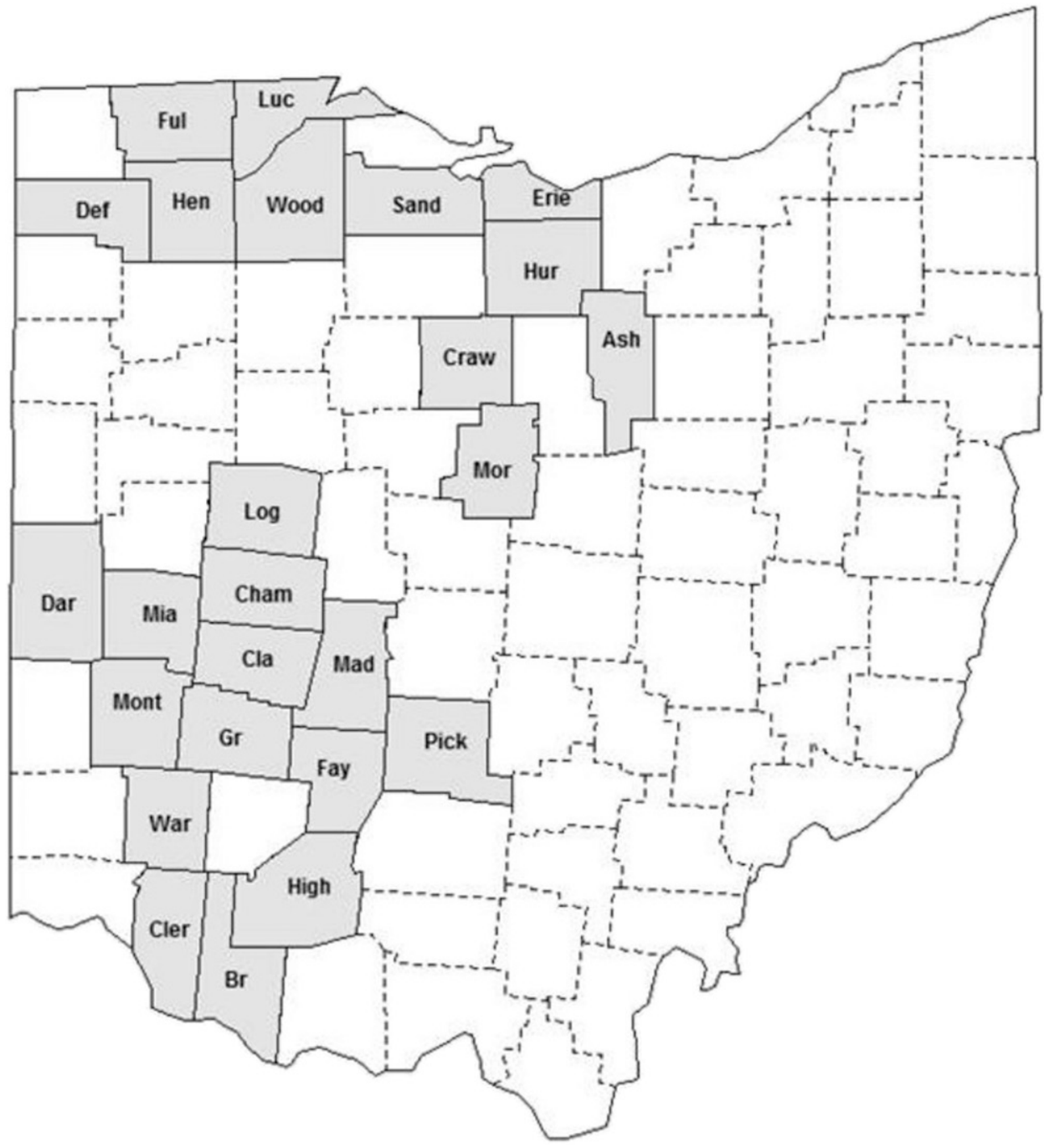

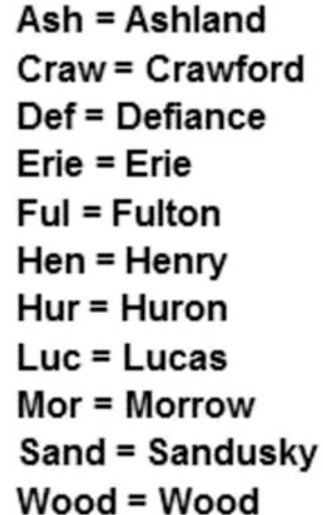

$\mathrm{Br}=$ Brown Cham $=$ Champaign $\mathrm{Cla}=$ Clark Cler $=$ Clermont Dar $=$ Darke Fay $=$ Fayette $\mathrm{Gr}=\mathrm{Green}$ High $=$ Highland Log $=$ Logan Mad $=$ Madison Mia $=$ Miami Mont $=$ Montgomery Pick = Pickaway War $=$ Warren

Fig. 1. Location of regions and respective counties where isolates of Pythium irregulare complex were recovered from soybean and corn production fields in Ohio. In this study, based on the number of the isolates, the area was divided into two main macro regions designated as Northwest (North, North-central, and Northeast soil regions), and Southwest (South-central and South soil regions). 
plug was transferred to the center of a $100 \times 15 \mathrm{~mm}$ Petri dish containing PCA media with $1.2 \%$ agar, and allowed to grow for 3 days at $20^{\circ} \mathrm{C}$. Soybean seeds were surface sterilized in a $0.525 \%$ sodium hypochlorite solution for $1 \mathrm{~min}$, rinsed twice in sterile deionized water, and allowed to dry in a laminar flow hood for $30 \mathrm{~min}$. Ten soybean seeds were placed into the Petri dishes containing 3-day-old colonies, and were incubated at $20^{\circ} \mathrm{C}$ in the dark. After 7 days, the number of germinated seeds was counted in each plate. A seed was considered germinated if the radicle was more than $1 \mathrm{~cm}$ long and no visible necrosis or browning of the roots were observed. The susceptible cultivar Kottman and the moderately susceptible cultivar Dennison (Balk 2014) were used for the assay. Aggressiveness was scored as follows (Supplementary Fig. S1): $0=100 \%$ germination and no symptoms; $1=70$ to $99 \%$ germination and lesions on roots; $2=30$ to $69 \%$ germination with coalesced lesions; $3=0$ to $29 \%$ germination and all seed tissues colonized. A noninoculated control was added for each cultivar to verify germination and identify the presence of seedborne pathogens. If seedborne pathogens were present, those seeds were removed from the final data. The experiment was performed twice in a completely randomized design with three replicate plates for each isolate. Since seed germination was expressed as percentage of total seeds used in each plate, the values were transformed to arcsine square root and statistical analysis was performed with PROC MIXED using SAS 9.4 (SAS Inc., Cary, NC) with isolate, soybean cultivar, and interaction as fixed factors, and experiment and replication nested within experiment as random factors. Data were back transformed for presentation of the results.

Isolate aggressiveness in seedling root rot assay. A cup assay to measure the level of root rot was performed according to methodology previously described (Balk 2014; Ellis et al. 2013). Briefly, spawn bags (Myco Supply, Pittsburgh, PA) containing $950 \mathrm{ml}$ of play sand (Quikrete, Atlanta, GA), $50 \mathrm{ml}$ of cornmeal (The Quaker Oats Company, Chicago, IL), and $250 \mathrm{ml}$ of deionized water were autoclaved for $30 \mathrm{~min}$ in two consecutive days. Ten mycelial plugs $\left(10 \mathrm{~mm}\right.$ diameter) of a specific isolate, previously grown at $20^{\circ} \mathrm{C}$ for 3 days in $60 \times 15 \mathrm{~mm}$ Petri dishes containing PCA, were placed into a sterile spawn bag. The bags were sealed with a sealer-electrical impulse (Harbor Freight Tools, Calabasas, CA) and maintained at room temperature for 9 days. They were shaken every other day for approximately 2 min to allow for uniform colonization of the media by the pathogen.

The colonized sand-cornmeal media was mixed with fine vermiculite (Perlite Vermiculite Packaging Industries, North Bloomfield, $\mathrm{OH}$ ) in a ratio of 1:4 based on volume. Holes were made with a pencil at the bottom of 473-ml styrofoam cups (Dart Container Corporation, Mason, MI) to allow for water drainage; $100 \mathrm{ml}$ of coarse vermiculite (Perlite Vermiculite Packaging Industries, North Bloomfield, $\mathrm{OH}$ ) was then placed in the bottom, followed by $300 \mathrm{ml}$ of the inoculum and fine vermiculite mixture. The cups were kept at $20^{\circ} \mathrm{C}$, and watered three times over a period of $24 \mathrm{~h}$. Eight soybean seeds were then placed directly on the inoculum mixture and covered with $100 \mathrm{ml}$ of coarse vermiculite. The cups were maintained in a growth chamber set at $20^{\circ} \mathrm{C}, 14: 10 \mathrm{~h}$ cycle of light/dark, and $60 \%$ relative humidity. Cups were watered three times a day with nonsterile deionized water. Stand count data were collected at 7 and 14 days after planting (dap), and a seedling was considered emerged if the cotyledons were above the coarse vermiculite surface. Data for root rot, root and shoot weight were collected at 14 dap at VC growth stage (unifoliate leaves expanded). Plants were removed from the cups and after washing off the vermiculite and inoculum with tap water, they were placed and wrapped in wet paper towels, which were kept in a plastic bag at $4^{\circ} \mathrm{C}$ until processed. Plants were scored for root rot based on the scale (Supplementary Fig. S2): $1=$ no lesions, healthy roots; $2=$ lesions on of 1 to $20 \%$ of the lateral roots; $3=$ lesions on tap root and 21 to $75 \%$ of the lateral roots; $4=$ lesions on tap root and $>75 \%$ of the lateral roots; $5=$ no germination of seed (Balk 2014). Mean plant height was determined based on the measurement of three plants. Fresh root and shoot weight was also determined, and the values were expressed by plant according to the final stand count.
Due to limited space in the growth chamber, the experiment was performed in an incomplete block design with half of the isolates evaluated in each run of the experiment. The isolates $\mathrm{Br}-2-3-5$ and Gr-1-5-1 were used as controls and were present in all runs of the experiment. A noninoculated control was also added to each assay to verify seed germination, pathogen contamination, and growth conditions. The soybean cultivars Dennison and Kottman were used for all the assays. Each treatment (isolate $\times$ cultivar) was replicated three times within the experiment, and the assay was completed twice for each isolate. Nonparametric analysis was performed with the disease scores following the approach described by Shah and Madden (2004). Data were rank-transformed and lsmeans of ranks were computed. The relative effect (RE) of each treatment was calculated and Wald-type statistics were obtained. Emergence at 7 dap, emergence at 14 dap, plant height, fresh root weight per plant, and fresh shoot weight per plant were analyzed with PROC MIXED using SAS 9.4 (SAS Inc., Cary, NC) with isolate, cultivar, and interaction as fixed factors, and experiment and replication nested within experiment as random factors. Lsmeans were calculated and contrast statements were used to compare the main and simple effect means for all significant fixed effects and interactions.

Fungicide sensitivity assay. Sensitivity to metalaxyl fungicide was evaluated with an amended potato carrot broth (PCB) assay adapted from Olson et al. (2013). Sterile PCB (20 g carrots and $20 \mathrm{~g}$ potatoes per liter) that had cooled to $50^{\circ} \mathrm{C}$ was amended with technical grade metalaxyl (Syngenta, Greensboro, NC) dissolved in $1 \mathrm{ml}$ dimethylsulfoxide (DMSO) to final concentrations of 0,5 , and $100 \mu \mathrm{g} \mathrm{ml}^{-1}$. DMSO was also added to the control. A 3-mm mycelia plug from culture grown for 3 days was placed in a well of a 24well cell culture plate (Corning Inc., Corning, NY) containing PCB only, PCB $+5 \mu \mathrm{g} \mathrm{ml}^{-1}$, and PCB $+100 \mu \mathrm{g} \mathrm{ml}^{-1}$ of metalaxyl (Supplementary Fig. S3). A noninoculated control was added to verify possible contamination in the liquid media. The plates were placed in a plastic bag and maintained at $20^{\circ} \mathrm{C}$ in the dark. After $48 \mathrm{~h}$, the plates were examined under a stereoscope (10× magnification) and mycelial growth was scored based on a scale: $0=$ no growth; $1=$ microscopic sporadic hyphae growing from the plug, no uniformity; 2 = microscopic uniform hyphae growth; $3=$ uniform mycelium and visible macroscopically; $4=$ mycelium uniform, 85 to $95 \%$ of growth compared with the nonamended control; $5=$ mycelium growth the same as nonamended control. Each treatment (isolate $\times$ fungicide concentration) was replicated three times within the experiment, and the assay was completed twice. Since mycelial growth was assessed in an ordinal scale, nonparametric analyses were performed following approach described by Shah and Madden (2004) for factorial experiments using PROC RANK and PROC MIXED of SAS (SAS Inc., Cary, NC). Data were ranktransformed and lsmeans of ranks were computed. The relative effect (RE) of each treatment was calculated and Wald-type statistics were obtained.

Morphological studies. Three isolates from each SSR group were selected for morphological studies on grass blade cultures (Waterhouse 1967). Leaf blades of ryegrass grown at $25^{\circ} \mathrm{C}$ with a $12-\mathrm{h}$ light cycle were cut from young tissue and added to $200 \mathrm{ml}$ of deionized water. The water and the grass blades were autoclaved for $30 \mathrm{~min}$ on two consecutive days. Three sterile grass blades were placed in a $60 \times 15 \mathrm{~mm}$ Petri dish containing $5 \mathrm{ml}$ of $10 \%$ sterile soil extract (Moorman et al. 2002). Four 3-mm mycelial plugs from a 3-day-old PCA culture were added to the plates in contact with the grass blades. Plates were maintained at $20^{\circ} \mathrm{C}$ for 3 to 7 days. The morphology of oospore, oogonia, and sporangia was observed under a compound microscope equipped with a digital camera (AmScope, Irvine, CA). Twenty oospores were randomly selected for measurement under a compound microscope (Matsumoto et al. 2000). Another plate was prepared for each isolate and after 3 days in the dark at $20^{\circ} \mathrm{C}$, the soil extract was discarded and another $5 \mathrm{ml}$ of $10 \%$ sterile soil extract was added. Cultures were transferred to $15^{\circ} \mathrm{C}$ with a $12 \mathrm{~h}$ light-dark cycle. Zoospore release was monitored every $2 \mathrm{~h}$. Twenty sporangia were randomly selected for measurement of the diameter under a compound microscope (Matsumoto et al. 2000). 


\section{Results}

ITS sequence analysis. Sequences from the ITS region (ITS15.8S-ITS2) from 53 isolates previously recovered from soybean and corn fields in Ohio were compared with 11 sequences selected to represent the different groups used to describe the intraspecific diversity within $P$. irregulare. Distance analysis using the UPGMA algorithm indicated that there are three main groups with bootstrap support higher than $90 \%$. Four isolates from four different counties clustered with $P$. cryptoirregulare, and the remaining 49 isolates could be divided into two groups (Fig. 2). Group 1 included 26 isolates representing 13 counties, and they clustered with the $P$. irregulare neotype CBS250.28 from Lévesque and De Cock (2004), $P$. irregulare group I from Matsumoto et al. (2000), and three sequences of $P$. irregulare s.s. from Garzón et al. (2007). Group 2 was composed of 23 isolates representing 14 counties that clustered
A

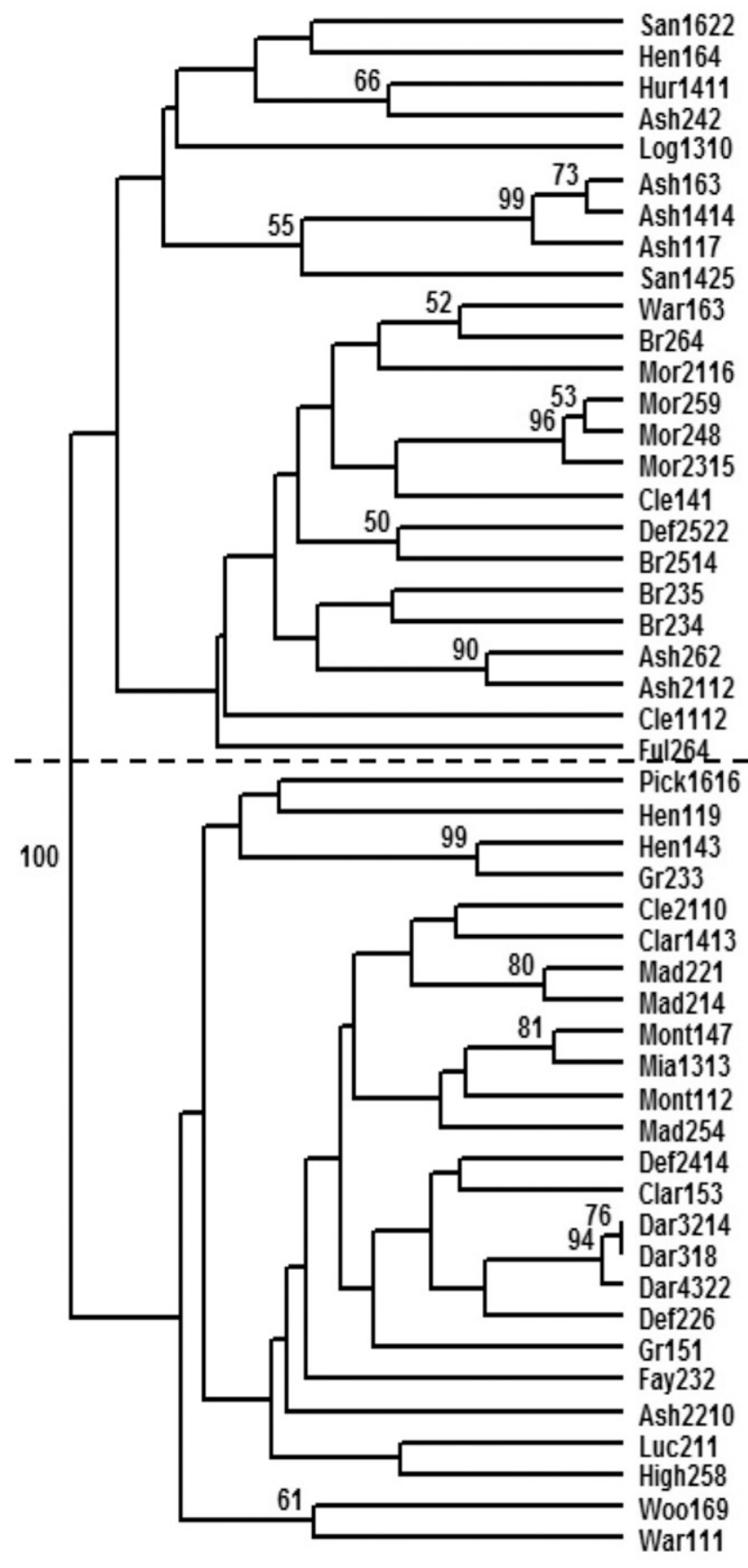

ITS

을

$\stackrel{\circ}{\circ} \stackrel{\circ}{i}$ i

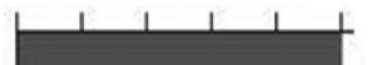

1

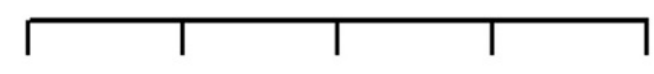

$\begin{array}{lllll}0.4 & 0.3 & 0.2 & 0.1 & 0\end{array}$

Fig. 2. A, Unweighted pair group method with arithmetic mean (UPGMA) dendrogram of Pythium irregulare isolates based on Bruvo's genetic distance obtained with simple sequence repeat (SSR) markers and their respective ITS groups. $\mathrm{B}$, Bar plot of clusters $(\mathrm{K}=2)$ assigned by STRUCTURE based on 19 microsatellite loci to $P$. irregulare species complex isolates from soybean fields from different regions in Ohio. Dark gray represents group 1 and light gray represents group 2 of $P$. irregulare. 
with two sequences of $P$. irregulare s.s. from Garzón et al. (2007). The two $P$. irregulare groups differed by the presence of five nucleotide substitutions positioned at $216 \mathrm{bp}$ (A/G), $294 \mathrm{bp}$ (T/G), $757 \mathrm{bp}$ (T/C), $761 \mathrm{bp}(\mathrm{C} / \mathrm{T})$, and $822 \mathrm{bp}(\mathrm{A} / \mathrm{G})$ in the ITS sequence.

Population analyses. Population analysis was performed with the 49 isolates that mostly clustered with $P$. irregulare group 1 and 2 based on the ITS sequence analysis. Each of the 21 SSR primer pairs amplified at least one locus for almost all of the isolates (Supplementary Table S2). Two SSR markers (SSR4 and SSR8) were monomorphic, and therefore were not included in further analyses. For the 19 SSR markers that were informative, there were four to 11 alleles observed per locus, and in total, 129 alleles were scored with an average of 6.8 alleles per locus. Putative heterozygosity was detected for 13 loci with the presence of two bands for six isolates. Each isolate had its own distinct multilocus genotype and no clones were identified among the 49 isolates from Ohio in this study. Even though population genetic analysis did not include the four isolates of $P$. cryptoirregulare, it is relevant to mention that each SSR marker amplified a product for these isolates, which indicated that cross-amplification does occur between two closely related species. In addition, no clones were identified among these four isolates.

Allele frequency analysis considering region as population parameter revealed lower numbers of alleles, expected heterozygosity, and Shannon's information index in the Southwest region compared with the Northwest region. The alleles detected in the isolates from the Northwest region could be found in isolates from the Southwest region and vice versa. As a result, low to moderate genetic differentiation $\left(F_{S T}=0.06\right)$ was observed between the two regions, and gene flow analysis $(\mathrm{Nm}=4.34)$ suggested genetic exchange or migration between the regions. The results at the region level were further supported by AMOVA (Table 2), where moderate genetic differentiation was observed between regions $\left(F_{S T}=0.071\right)$. Moreover, $90.09 \%$ of the genetic variation was observed among individuals and $7.07 \%$ between populations.

Cluster analysis of SSR data with UPGMA algorithm revealed two main clusters (Fig. 2A), which, with the exception of two isolates (Pick-1-6-16 and High-2-5-8), mostly agreed with the ITS groups. Based on STRUCTURE analysis, an optimal value of two populations $(K=2)$ best fit the data (Supplementary Fig. S4) and the clustering of the isolates agreed with both ITS and SSR groups (Fig. 2B), but they were not associated with region of origin (Fig. 3).

Mycelial growth rate at different temperatures. All isolates were able to grow from $12^{\circ} \mathrm{C}$ up to $36^{\circ} \mathrm{C}$; however, considerable reduction in growth rate was observed at $36^{\circ} \mathrm{C}$ (Fig. 4). There was a significant effect $(P<0.001)$ of isolate group, temperature, and interaction on the mycelial growth rate. There was a significant difference $(P<0.05)$ in the growth rates of $P$. irregulare group 2 compared with group 1 and $P$. cryptoirregulare for all temperatures, except at $36^{\circ} \mathrm{C}$ (Fig. 4). Furthermore, no significant $(P>0.05)$ statistical difference was observed between the growth rate of $P$. irregulare group 1 and $P$. cryptoirregulare (Supplementary Table S3). The optimal growth temperature for all the groups occurred between 26 to $29^{\circ} \mathrm{C}$.

Aggressiveness in seed plate assay. All of the isolates were pathogenic and very aggressive toward both soybean cultivars Dennison and Kottman in the seed plate assay. There was no interaction between isolate groups and soybean cultivars within $P$. irregulare group 1 and $P$. cryptoirregulare. However, within $P$. irregulare group 2 , all isolates but two (Gr-1-5-1 and Def-2-4-14) caused 100\% inhibition of seed germination and complete colonization of the seeds (data not shown).

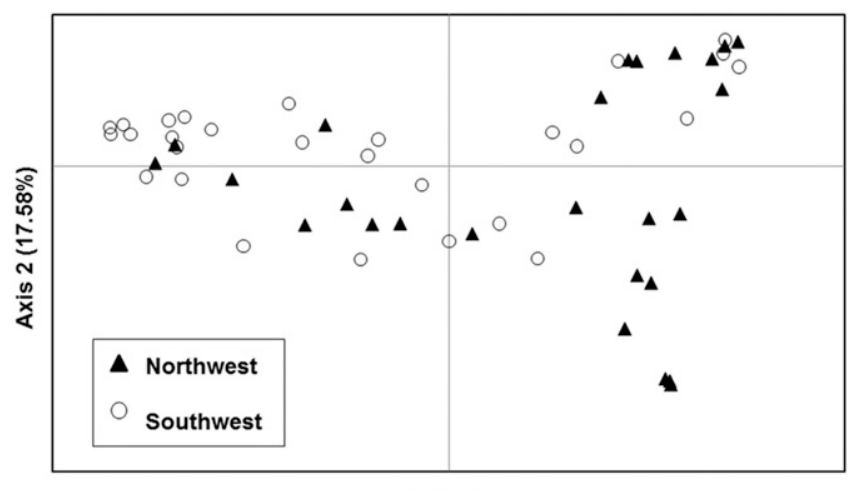

Axis $1(35.79 \%)$

Fig. 3. Scatter plot of the first and second coordinate from principal coordinate analysis (PCOA) of pairwise genetic distances of multilocus genotypes of Pythium irregulare isolates from soybean fields in the Northwest $(n=26$; triangles) and Southwest ( $n=28$; circles) regions in Ohio. The multilocus genotypes were based on simple sequence repeat (SSR) data.

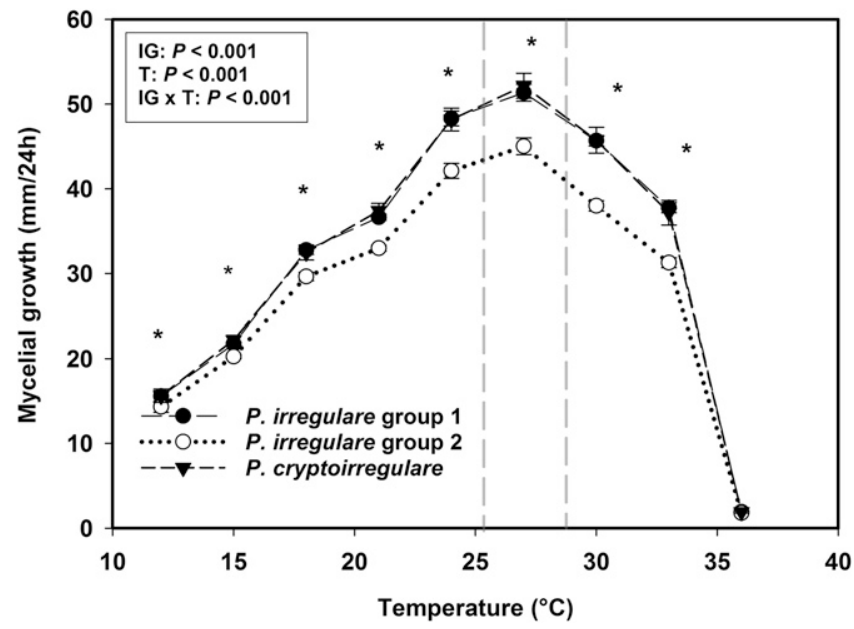

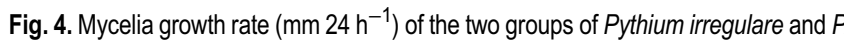
cryptoirregulare obtained from soybean fields in Ohio at different temperatures. Groups were determined by cluster analysis based on 19 simple sequence repeat (SSR) markers. Bars represent the standard error of the mean at each temperature Probability $(P)$ values are indicated in the box for each source of variation: isolate groups $(I G)$, temperature $(T)$, and interaction IG $\times$ T. Asterisks indicate that $P$. irregulare group 2 was significantly different $(P<0.05)$ from the other groups based on contrast analysis. The range of optimum growth temperature is indicated by the gray vertical lines.

Table 2. Analysis of molecular variance (AMOVA) a between and within populations of isolates of Pythium irregulare from soybean and corn production fields in Ohio determined with 21 simple sequence repeat (SSR) markers

\begin{tabular}{|c|c|c|c|c|c|c|c|c|}
\hline \multirow[b]{2}{*}{ Source of variation } & \multirow[b]{2}{*}{ df } & \multirow[b]{2}{*}{ Sum of squares } & \multirow[b]{2}{*}{ Mean square } & \multicolumn{2}{|c|}{ Estimated variation } & \multirow[b]{2}{*}{$F_{S T}^{b}$} & \multirow[b]{2}{*}{$P$} & \multirow[b]{2}{*}{$N m^{\mathrm{c}}$} \\
\hline & & & & Decimal & $\%$ & & & \\
\hline Between populations & 1 & 39.89 & 39.89 & 0.53 & 7.07 & 0.071 & 0.001 & 3.284 \\
\hline Among individuals & 47 & 649.43 & 13.82 & 6.80 & 90.09 & $\ldots$ & $\ldots$ & $\ldots$ \\
\hline Within individuals & 49 & 10.50 & 0.21 & 0.21 & 2.84 & $\ldots$ & $\ldots$ & $\ldots$ \\
\hline
\end{tabular}

${ }^{a}$ AMOVA performed with GenALEx v. 6.5 (Peakall and Smouse 2012) using 999 permutations.

${ }^{\mathrm{b}}$ Fixation index: $F_{S T}<0.05=$ low genetic differentiation; $0.05<F_{S T}<0.15=$ moderate; $0.15<F_{S T}<0.25=$ great $F_{S T}>0.25=$ very great.

${ }^{\mathrm{c}} \mathrm{Nm}=$ absolute number of migrants per generation: $\mathrm{Nm}>1$ = great gene flow; $0.5<\mathrm{Nm}>1=$ weak gene flow, but exchange of alleles may still occur; $\mathrm{Nm}<0.5=$ groups almost fully genetically isolated (Milgroom 2015). 
Aggressiveness in growth chamber. Symptoms of root rot characterized by brown discoloration and limited development of the root system were observed on both soybean cultivars, Dennison and Kottman, following inoculation of isolates of $P$. irregulare group $1, P$. irregulare group 2 , and $P$. cryptoirregulare. Based on the statistical analysis within each group, there were significant effects of isolate for the severity of seed, seedling, and root rot for $P$. irregulare group 1 and $P$. irregulare group 2 (Supplementary Table S4). However, among the four isolates of $P$. cryptoirregulare, there were only significant effects for the mean seedling emergence, fresh root weight, and root rot score. Soybean cultivar was also significantly different for the mean plant height and fresh root weight among the isolates within $P$. irregulare group 1 and $P$. irregulare group 2, and fresh root weight within $P$. cryptoirregulare. The isolate by soybean cultivar interaction was not significant within each group. Even though all of the isolates were pathogenic, they differed in the level of aggressiveness for emergence at 14 dap, fresh root weight, and root rot score (Fig. 5). Very similar trends were also observed for
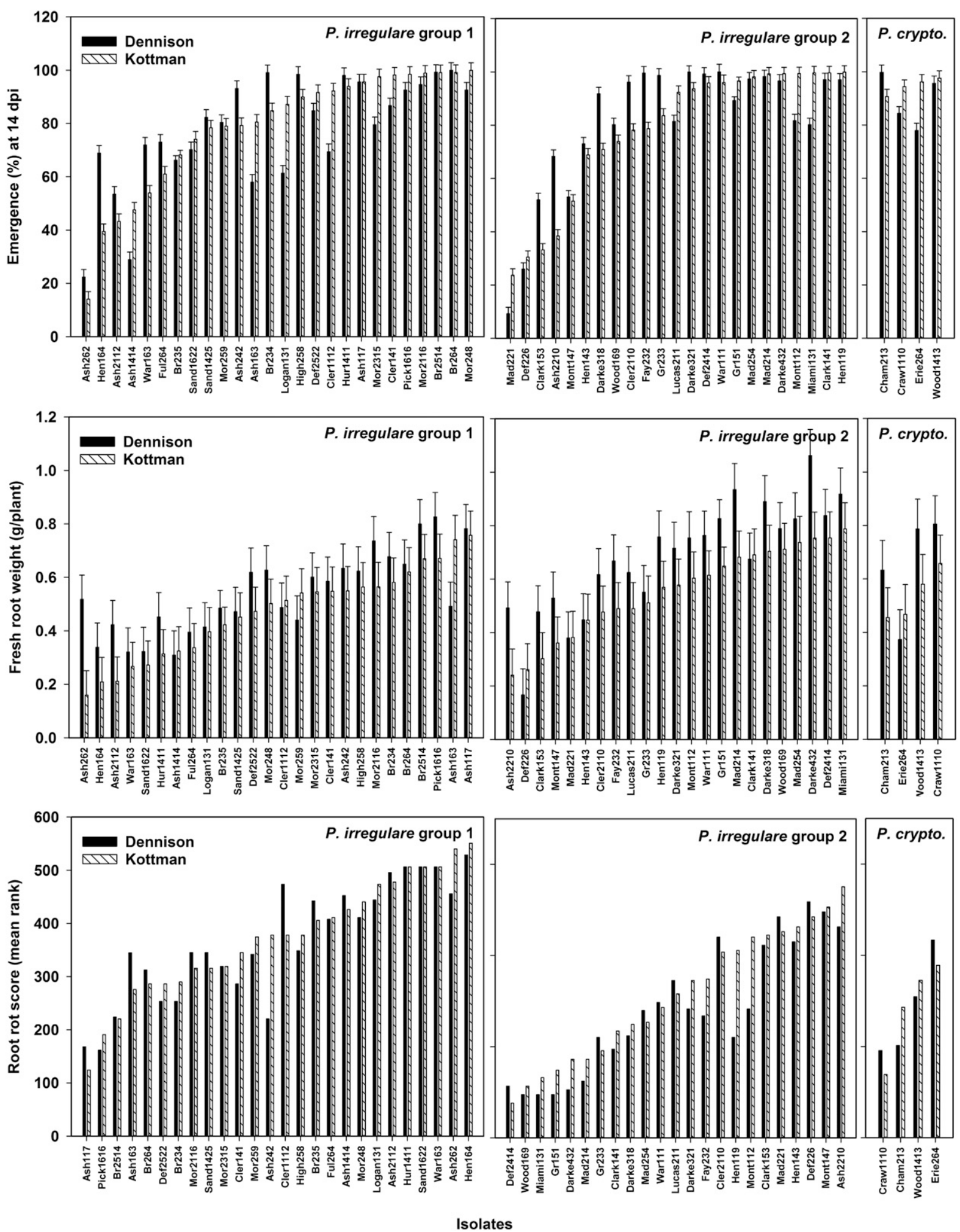

Fig. 5. Emergence at 14 days after planting (E14dap, \%), fresh root weight (FRW, g) and root rot score (RRS) of the soybean cultivars Dennison (black bar) and Kottman (white bar) inoculated with different isolates of Pythium irregulare group 1, P. irregulare group 2, and P. cryptoirregulare. The bars represent the least square means with the standard errors. 
emergence at 7 dap, plant height, and fresh shoot weight (data not shown). Isolates of $P$. irregulare group 1 were more aggressive based on the higher mean rank of root rot score, followed by $P$. irregulare group 2 and $P$. cryptoirregulare (Supplementary Table S5).

Fungicide sensitivity assay. All 53 isolates were screened for sensitivity to metalaxyl at $5 \mu \mathrm{g}$ a.i. $\mathrm{ml}^{-1}$ and $100 \mu \mathrm{g}$ a.i. $\mathrm{ml}^{-1}$ in a $24-w e l l$ plate bioassay. At 48 hours postinoculation, mycelial growth ratings ranged from 2.0 to 4.0 and from 2.0 to 3.0 for media amended with $5 \mu \mathrm{g}$ a.i. $\mathrm{ml}^{-1}$ and $100 \mu \mathrm{g}$ a.i. $\mathrm{ml}^{-1}$ of metalaxyl, respectively (Fig. 6). There was significant effect of isolate, fungicide concentration, and interaction on mycelial growth for all three groups (Supplementary Table S6) and high variability of isolates was observed within each group (data not shown). In this study, 35.8\% $(n=19)$ of the isolates were considered sensitive and $64.2 \%(n=34)$ of the isolates were considered insensitive at $100 \mu \mathrm{g}$ a.i. $\mathrm{ml}^{-1}$. In all, from the 34 isolates insensitive to metalaxyl, 18 belong to $P$. irregulare group 1,15 to $P$. irregulare group 2, and one belongs to $P$. cryptoirregulare.

Morphological studies. Measurements of morphological features (Fig. 7) indicated that hyphae varied from 2.29 to $4.97 \mu \mathrm{m}$ wide (Supplementary Table S7). All of the isolates formed globose to subglobose sporangia. In addition, intercalary or terminal globose and subglobose oogonia were formed. The mean diameter of the oogonium was $17.13 \pm 1.50 \mu \mathrm{m}, 18.00 \pm 2.37 \mu \mathrm{m}$, and $19.10 \pm$ $2.49 \mu \mathrm{m}$ for $P$. irregulare group $1, P$. irregulare group 2 , and $P$. cryptoirregulare, respectively. Oospores were mostly aplerotic, and the diameter averaged from $14.14 \pm 1.42 \mu \mathrm{m}$ in $P$. irregulare group $1,15.26 \pm 2.36 \mu \mathrm{m} P$. irregulare group 2 , and 16.21 \pm $2.31 \mu \mathrm{m}$ in $P$. cryptoirregulare. The mean diameter of the ooplast was $9.59 \pm 2.81$ in $P$. irregulare group $1,10.14 \pm 1.66 \mu \mathrm{m}$ in $P$. irregulare group 2 , and $10.80 \pm 2.38 \mu \mathrm{m}$ in $P$. cryptoirregulare. The antheridia were predominantly monoclinous, but some diclinous antheridia were also observed. The number of antheridia per oogonium ranged from one to three. There were significant differences among the groups for all features evaluated. In addition, significant differences among isolates were observed within $P$. irregulare group 1 for hyphae and ooplast, within $P$. irregulare group 2 for oospore and ooplast, and within $P$. cryptoirregulare for sporangia, hyphae, oogonia, and oospores.

\section{Discussion}

This study analyzed the genetic diversity, population structure, aggressiveness, sensitivity to metalaxyl, and morphological features of $P$. irregulare recovered from soybean and corn production fields in Ohio. A comparison of the ITS region of 53 isolates from Ohio with sequences from other studies deposited in NCBI identified three groups: group $1(n=26)$ and $2(n=23)$ that corresponded to subdivisions of $P$. irregulare (Garzón et al. 2005a; Matsumoto et al. 2000), and group $3(n=4)$ that clustered with P. cryptoirregulare (Garzón et al. 2007). Two main clusters within $P$. irregulare from SSR analysis also corresponded to the ITS groups 1 and 2, with exception of two isolates. Differences in mycelial growth rate, aggressiveness, and sensitivity to metalaxyl were observed among and within the groups, which may have implications for germplasm screening and assessment of fungicide efficacy.

Genetic diversity and population structure of $P$. irregulare from three forestry nurseries' soils in Oregon and Washington was recently studied by Weiland et al. (2015). In that population of 48 isolates, $19 \%$ of the SSR markers were polymorphic and three to six alleles were observed per locus. For $P$. irregulare population in Ohio, $90 \%$ of the markers were polymorphic, and four to 11 alleles observed per locus based on gel electrophoresis. The observed heterozygosity of 0.53 from the study by Weiland et al. (2015) is considerably higher compared with our results $\left(H_{o}=0.02\right)$. While the same SSR markers were used in these studies, the difference in the number of alleles per locus may be a reflection of the actual number of fields that were sampled as well as differences due to demography, environment, and host plants. Evolutionary forces could be acting differently in intensive agriculture for grain production compared with less disturbed forestry nurseries.

Each of the 49 isolates of $P$. irregulare in this study is a unique genotype. High levels of diversity among isolates was also observed by
Harvey et al. (2001), who identified 31 multilocus genotypes among a total of 34 isolates from wheat, medic, or subclover in Australia. In contrast, among the 48 isolates of $P$. irregulare recovered from forestry nursery soils by Weiland et al. (2015), 16 isolates presented unique AFLP profiles whereas 32 isolates were classified into 11 clonal lineages with up to six isolates per lineage.

The two main groups identified in this study based on cluster analysis were not associated with region of origin (Northwest and Southwest), similar to what was observed by other authors (Harvey et al. 2000, 2001; Weiland et al. 2015). As a result, low to moderate genetic differentiation of $P$. irregulare was observed at region level $\left(\mathrm{F}_{\mathrm{ST}}=\right.$ 0.071), which is similar to what Weiland et al. (2015) observed among forestry nurseries $\left(\mathrm{F}_{\mathrm{ST}}=0.076\right)$. Moreover, in both cases, the number of migrants $(\mathrm{Nm})$ per generation was higher than 1 , which demonstrated that the same alleles in isolates from one location could
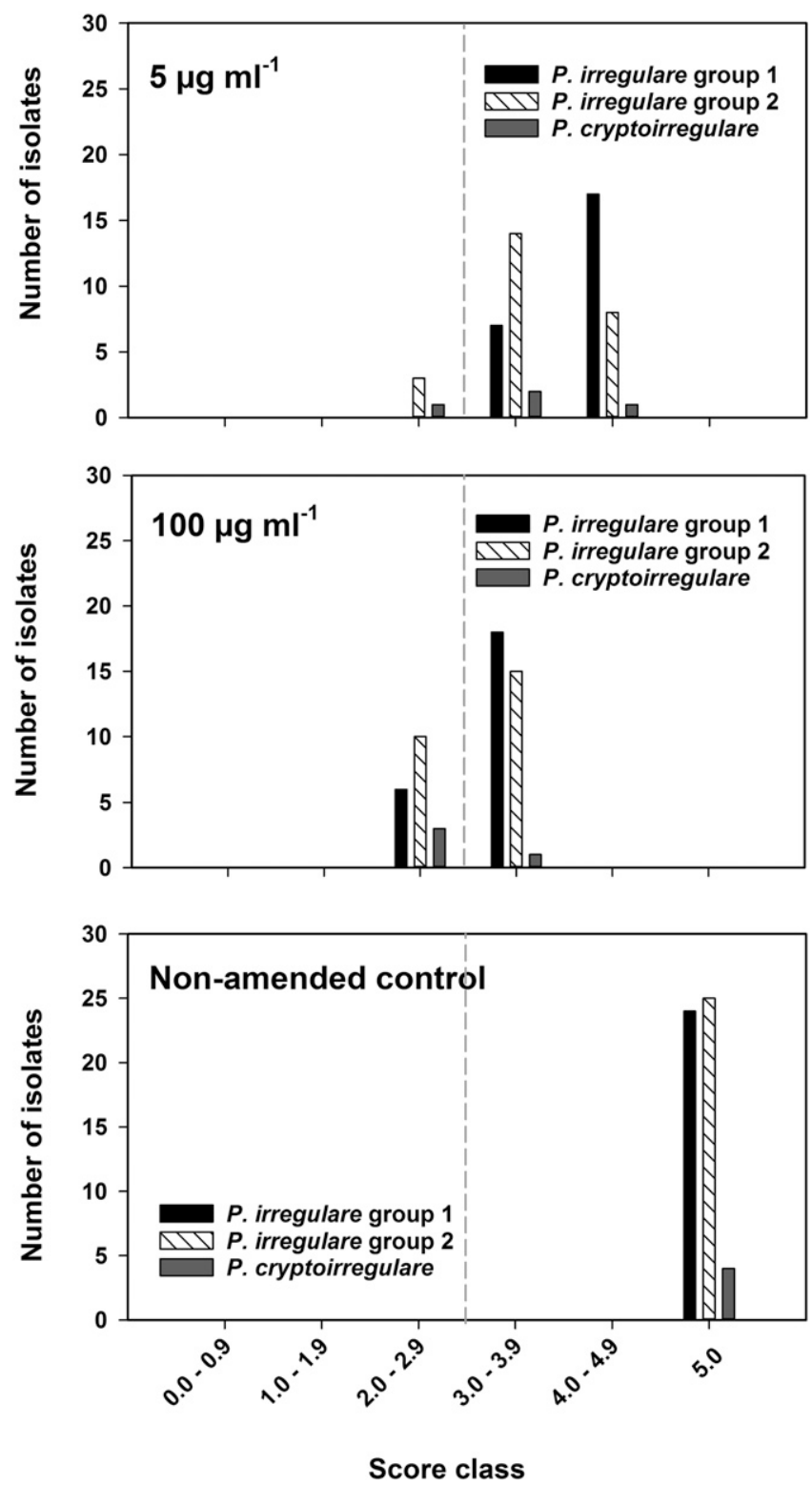

Fig. 6. Histogram of the distribution of the median scores for mycelial growth of isolates of Pythium irregulare group $1(n=26), P$. irregulare group $2(n=23)$, and $P$. cryptoirregulare $(n=4)$ tested in potato carrot broth nonamended, and amended with 5 or $100 \mu \mathrm{g} \mathrm{ml}^{-1}$ of metalaxyl. Growth was rated at $48 \mathrm{~h}$ postinoculation based on the scale adapted from Olson et al. (2013): $0=$ no growth; $1=$ microscopic sporadic hyphae growing from the plug, no uniformity; $2=$ microscopic uniform hyphae growth; $3=$ uniform mycelium and visible macroscopically; $4=$ mycelium uniform, 85 to $95 \%$ of growth compared with the nonamended control; $5=$ mycelium growth the same as nonamended control. Isolates with score of less than 3 are considered sensitive, and 3 to 5 are insensitive to metalaxyl. 
be found in isolates from another location. Migration of genotypes from one location to another for a soilborne pathogen such as $P$. irregulare tends to be limited but still possible. Weiland et al. (2015) suggested that movement of soil and plant material from one nursery to another occurs in Oregon and Washington. A similar scenario was pointed out by Lee et al. (2010) who also proposed movement of inoculum among greenhouses to explain the lack of genetic differentiation of populations of $P$. aphanidermatum recovered from ornamental plants in Pennsylvania. In our study, however, considering that soybean is an annual crop usually in rotation with corn or wheat, migration may occur with movement of soil by soil peds in seed lots or more commonly by dirty equipment.

Low genetic variability is usually expected for homothallic organisms such as $P$. irregulare where sexual reproduction occurs by selffertilization. However, Harvey et al. (2001) observed heterozygosity based on RFLP analysis, and after crossing isolates and performing segregation analysis, the researchers confirmed outcrossing of $P$. irregulare under laboratory conditions. In this study, putative heterozygosity was observed in 13 SSR loci for some isolates. Interestingly, heterozygosity was most frequently observed for the isolates that clustered with $P$. cryptoirregulare. Putative heterozygosity was also detected with SSR markers with the homothallic oomycete Phytophthora sojae (Stewart et al. 2016).

Host resistance is known to apply selection pressure on pathogen populations (Milgroom 2015). In this study, no interaction between isolate and cultivar was observed. The soybean cultivar Dennison is moderately susceptible to $P$. irregulare, whereas the cultivar Kottman is susceptible, and this same response was observed across all isolates in the growth chamber assay. However, significant differences in aggressiveness were observed among the groups and within groups. Even though there are no soybean cultivars with high levels of resistance to $P$. irregulare, some efforts have been directed toward germplasm screening for resistance to this pathogen (Bates et al. 2008; Ellis et al. 2013; Stasko et al. 2016). Therefore, the use of isolates that are genetically distinct and represent the different groups should be considered in future germplasm screening programs.

The isolates used in this study were very aggressive to the seeds, and 51 out of 53 isolates caused $100 \%$ inhibition of seed germination.
However, different levels of aggressiveness toward seedlings were observed among isolates within each group, but no interaction of isolate and soybean cultivar was observed. Isolates of $P$. irregulare were more aggressive than the four isolates of $P$. cryptoirregulare. Jiang et al. (2012) recovered isolates of Pythium spp. from corn-soybean rotation soil fields in Illinois, and the one isolate of $P$. cryptoirregulare had similar level of disease severity as those of $P$. irregulare.

Seed and seedling diseases of soybean have been primarily managed with fungicide seed treatments (Urrea et al. 2013), especially with metalaxyl and mefenoxam (Cohen and Coffey 1986; Dorrance et al. 2004). The repeated use of these fungicides may be a selection factor in the field because fungicide-insensitive isolates of $P$. irregulare were previously identified from soybean fields in Ohio (Balk 2014; Broders et al. 2007; Dorrance et al. 2004), and floriculture crops in North Carolina (Lookabaugh et al. 2015) and Pennsylvania (Moorman et al. 2002). Moreover, evidence of genetic differentiation with the presence of an AFLP fragment in metalaxyl-resistant and absence in metalaxyl-sensitive isolates was found in $P$. aphanidermatum (Garzón et al. 2005b). In this study, 64.2\% $(n=34)$ of the isolates were capable of growth on media amended with metalaxyl at $100 \mu \mathrm{g} \mathrm{ml}^{-1}$. This rate of metalaxyl or mefenoxam has been used in numerous fungicide sensitivity assays across many Pythium spp. (Brantner and Windels 1998; Broders et al. 2007; Garzón et al. 2005a; Moorman et al. 2002). Weiland et al. (2014) reported that isolates of $P$. irregulare had $\mathrm{EC}_{50}$ values for mefenoxam ranging from 0.05 to $0.56 \mu \mathrm{g} \mathrm{ml}^{-1}$, and isolates were considered resistant if the $\mathrm{EC}_{50}$ was equal or higher than $100 \mu \mathrm{g} \mathrm{ml}^{-1}$. According to Olson et al. (2013), isolates of Phytophthora sojae tested for sensitivity to mefenoxam in a 24-well bioassay at $100 \mu \mathrm{g}$ a.i. $\mathrm{ml}^{-1}$ with scores of less than 3 are considered as sensitive. In fungicide seed treatments, the recommended rate for management of Pythium seedling blight is usually lower than Phytophthora root rot (Giesler and Broderick 2016). Therefore, if Pythium spp. can grow uniformly at such high fungicide concentration it can be considered as insensitive. Therefore, insensitivity to metalaxyl is occurring independently and it is variable within groups and across the state of Ohio. These results contrast with what was observed by Garzón et al. (2005b), where all isolates of $P$. irregulare s.s. were sensitive to metalaxyl/mefenoxam, whereas resistant isolates

\section{P. irregulare group 1}
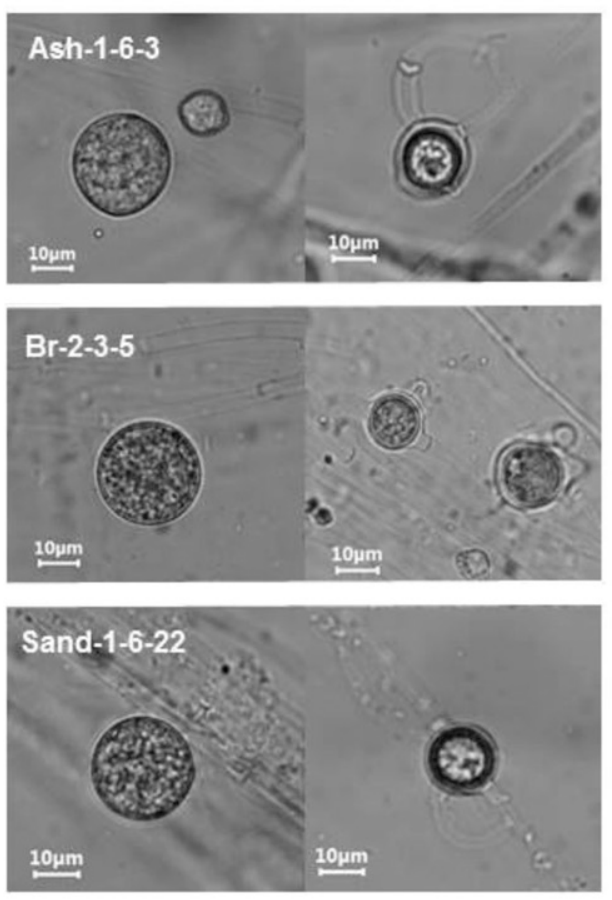

P. irregulare group 2
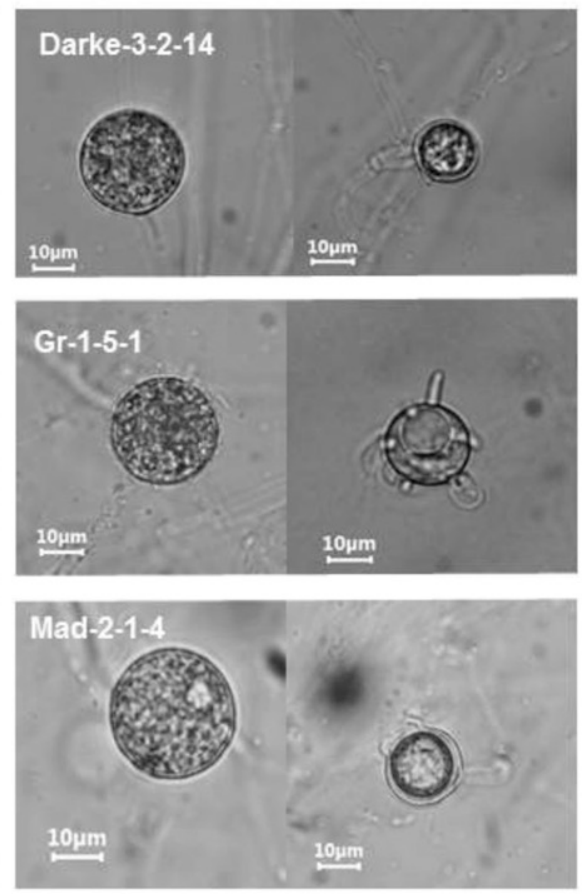

P. cryptoirregulare
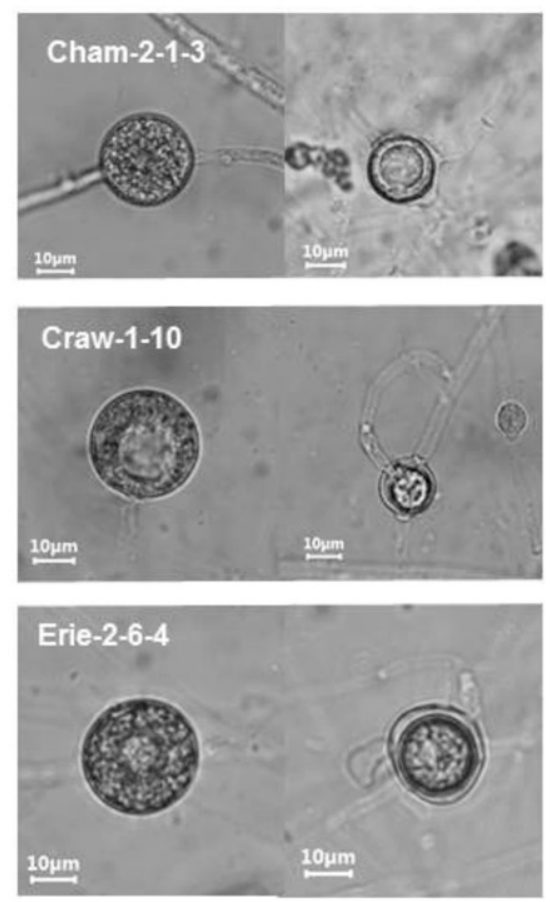

Fig. 7. Sporangia and oospore of representative isolates of Pythium irregulare group 1, $P$. irregulare group 2, and $P$. cryptoirregulare in grass blade cultures. 
were identified only in $P$. cryptoirregulare. These findings will impact the assessment of seed treatments with metalaxyl or when used in combinations, as isolates with and without sensitivity to this fungicide should be used.

The optimum growth temperature was the same for $P$. irregulare group $1, P$. irregulare group 2 , and $P$. cryptoirregulare; however, $P$. irregulare group 2 had an overall slower rate of growth. Matsumoto et al. (2000) observed that 28 to $30^{\circ} \mathrm{C}$ was the optimum temperature for growth of $P$. irregulare, but considerable difference in growth rate was observed between two groups at $33^{\circ} \mathrm{C}$. The growth of this pathogen at such high temperatures is astonishing since cool and wet conditions are usually considered as conducive for infection and disease development by this and other Pythium spp. Interestingly, reduction in the temperature is usually required for zoospore release (Waterhouse 1967), and this may be one of the most important factors associated with infections at cool temperatures. In the study by Wei et al. (2010) with isolates of $P$. irregulare from Canada, percentage of seed rot decreased with temperature and even at $20^{\circ} \mathrm{C}$, less than $60 \%$ of seed rot was observed, which is lower than what was verified for the isolates from Ohio. Aggressiveness and fungicide sensitivity for P. lutarium, $P$. oopapillum, $P$. sylvaticum, and $P$. torulosum are also influenced by temperature (Matthiesen et al. 2016). A possible explanation is the plasticity of $P$. irregulare for thermal tolerance as already observed for other plant pathogens (Lendenmann et al. 2016; Stefansson et al. 2013). Moreover, mycelial growth was measured as low as at $12^{\circ} \mathrm{C}$ and $15^{\circ} \mathrm{C}$. However, $15^{\circ} \mathrm{C}$ has been the recommended temperature for long-term storage of isolates (Erwin and Ribeiro 1996; Martin 1992) as well as room temperature (Zitnick-Anderson and Nelson 2015). In addition, P. torulosum was more aggressive at $13^{\circ} \mathrm{C}$ than at higher temperatures (Matthiesen et al. 2016). Thus, conditions for long term storage, particularly temperature, is something that should be reconsidered.

In this study, $P$. cryptoirregulare had significantly wider hyphae, and larger oogonia, oospore, ooplast, and sporangia compared with $P$. irregulare group 1. Garzón et al. (2007) also verified that $P$. cryptoirregulare presented significantly larger oogonia, oospore, and ooplast diameter compared with $P$. irregulare. Based on the subtle, but still statistically significant, differences in size among isolates from the two species, identification solely on morphology may not be practical as previously mentioned by Garzón et al. (2007).

Recommendation of soybean genotypes for a specific region is usually done based upon maturity groups and profile of resistance to a range of pathogens and insects. The results from this study demonstrated that there is greater diversity of $P$. irregulare populations and subpopulations have been established over time in Ohio. How this can influence management is not very well understood at this time. Nevertheless, the selection of isolates that represent the range of genetic diversity and levels of aggressiveness that are present in this region could help in screening and consequently the effective deployment of resistance. A larger number of samples per field and multiple fields within counties would be needed to better understand the number of subpopulations that may exist within a region.

\section{Acknowledgments}

We would like to thank Kirk Broders, who first collected soil and did the baiting to obtain the isolates used in the study, Damitha Wickramasinghe for her technical support in the early stages of this project, and the Molecular and Cellular Imaging Center of The Ohio State University for the assistance with sequencing.

\section{Literature Cited}

Alejandro Rojas, J., Jacobs, J. L., Napieralski, S., Karaj, B., Bradley, C. A., Chase, T., Esker, P. D., Giesler, L. J., Jardine, D. J., Malvick, D. K., Markell, S. G., Nelson, B. D., Robertson, A. E., Rupe, J. C., Smith, D. L., Sweets, L. E., Tenuta, A. U., Wise, K. A., and Chilvers, M. I. 2017. Oomycete species associated with soybean seedlings in North America-part I: identification and pathogenicity characterization. Phytopathology 107:280-292.

Al-Sa'di, A. M., Drenth, A., Deadman, M. L., De Cock, A. W. A. M., Al-Said, F. A., and Aitken, E. A. B. 2008. Genetic diversity, aggressiveness and metalaxyl sensitivity of Pythium spinosum infecting cucumber in Oman. J. Phytopathol. 156:29-35.

Balk, C. S. 2014. Assessment of resistance in soybean to Pythium ultimum and sensitivity of Ohio's diverse Pythium species towards metalaxyl. M.S. Thesis, Department of Plant Pathology, The Ohio State University, Columbus, OH.
Barr, D. J. S., Warwick, S. I., and Desaulniers, N. L. 1997. Isozyme variation, morphology, and growth response to temperature in Pythium irregulare. Can. J. Bot. 75:2073-2081.

Bates, G. D., Rothrock, C. S., and Rupe, J. C. 2008. Resistance of the soybean cultivar Archer to Pythium damping-off and root rot caused by several Pythium spp. Plant Dis. 92:763-766.

Brantner, J. R., and Windels, C. E. 1998. Variability in sensitivity to metalaxyl in vitro, pathogenicity, and control of Pythium spp. on sugar beet. Plant Dis. 82 896-899.

Brewer, M. T., and Milgroom, M. G. 2010. Phylogeography and population structure of the grape powdery mildew fungus, Erysiphe necator, from diverse Vitis species. BMC Evol. Biol. 10:268.

Broders, K. D., Lipps, P. E., Paul, P. A., and Dorrance, A. E. 2007. Characterization of Pythium spp. associated with corn and soybean seed and seedling disease in Ohio. Plant Dis. 91:727-735.

Broders, K. D., Wallhead, M. W., Austin, G. D., Lipps, P. E., Paul, P. A., Mullen, R. W., and Dorrance, A. E. 2009. Association of soil chemical and physical properties with Pythium species diversity, community composition, and disease incidence. Phytopathology 99:957-967.

Bruvo, R., Michiels, N. K., D’Souza, T. G., and Schulenburg, H. 2004. A simple method for the calculation of microsatellite genotype distances irrespective of ploidy level. Mol. Ecol. 13:2101-2106.

Chowdappa, P., Kumar, B. J. N., Kumar, S. P. M., Madhura, S., Bhargavi, B. R., and Lakshmi, M. J. 2016. Population structure of Phytophthora nicotianae reveals host-specific lineages on brinjal, ridge gourd, and tomato in South India. Phytopathology 106:1553-1562.

Cohen, Y., and Coffey, M. D. 1986. Systemic fungicides and the control of oomycetes. Annu. Rev. Phytopathol. 24:311-338.

Dorrance, A. E., Berry, S. A., Bowen, P., and Lipps, P. E. 2004. Characterization of Pythium spp. from three Ohio fields for pathogenicity on corn and soybean and metalaxyl sensitivity. Plant Health Prog.

Earl, D. A., and vonHoldt, B. M. 2012. STRUCTURE HARVESTER: a website and program for visualizing STRUCTURE output and implementing the Evanno method. Conserv. Genet. Resour. 4:359-361.

Ellis, M. L., McHale, L. K., Paul, P. A., St. Martin, S. K., and Dorrance, A. E. 2013 Soybean germplasm resistant to Pythium irregulare and molecular mapping of resistance quantitative trait loci derived from the soybean accession PI 424354. Crop Sci. 53:1008-1021.

Erwin, D. C., and Ribeiro, O. K. 1996. Phytophthora Diseases Worldwide. American Phytopathological Society Press, St. Paul, MN.

Evanno, G., Reginaut, S., and Goudet, J. 2005. Detecting the number of clusters of individuals using the software STRUCTURE: A simulation study. Mol. Ecol. 14:2611-2620.

Fernandez-Silva, I., Whitney, J., Wainwright, B., Andrews, K. R., Ylitalo-Ward, H., Bowen, B. W., Toonen, R. J., Goetze, E., and Karl, S. A. 2013. Microsatellites for next-generation ecologists: a post-sequencing bioinformatics pipeline. PLoS One 8:e55990.

Frenkel, O., Portillo, I., Brewer, M. T., Péros, J. P., Cadle-Davidson, L., and Milgroom, M. G. 2012. Development of microsatellite markers from the transcriptome of Erysiphe necator for analyzing population structure in North America and Europe. Plant Pathol. 61:106-119.

Garzón, C. D., Geiser, D. M., and Moorman, G. W. 2005a. Amplified fragment length polymorphism analysis and internal transcribed spacer and coxII sequences reveal a species boundary within Pythium irregulare. Phytopathology 95:1489-1498.

Garzón, C. D., Geiser, D. M., and Moorman, G. W. 2005b. Diagnosis and population analysis of Pythium species using AFLP fingerprinting. Plant Dis. 89:81-89.

Garzón, C. D., Yánez, J. M., and Moorman, G. W. 2007. Pythium cryptoirregulare, a new species within the $P$. irregulare complex. Mycologia 99:291-301.

Geiser, D. M., Dorner, J. W., Horn, B. W., and Taylor, J. W. 2000. The phylogenetics of mycotoxin and sclerotium production in Aspergillus flavus and Aspergillus oryzae. Fungal Genet. Biol. 31:169-179.

Giesler, L. J., and Broderick, K. C. 2016. Management of Phytophthora root and stem rot of soybean. NebGuide, Nebraska Extension. http://extensionpublications. unl.edu/assets/pdf/g1785.pdf

Goss, E. M., Larsen, M., Chastagner, G. A., Givens, D. R., Grünwald, N. J., and Howlett, B. J. 2009. Population genetic analysis infers migration pathways of Phytophthora ramorum in US nurseries. PLoS Pathog 5:e1000583.

Grünwald, N. L., Goodwin, S. B., Milgroom, M. G., and Fry, W. E. 2003. Analysis of genotypic diversity data for populations of microorganisms. Phytopathology 93:738-746.

Harvey, P. R., Butterworth, P. J., Hawke, B. G., and Pankhurst, C. E. 2000. Genetic variation among populations of Pythium irregulare in southern Australia. Plant Pathol. 49:619-627.

Harvey, P. R., Butterworth, P. J., Hawke, B. G., and Pankhurst, C. E. 2001. Genetic and pathogenic variation among cereal, medic and sub-clover isolates of Pythium irregulare. Mycol. Res. 105:85-93.

Hubisz, M. J., Falush, D., Stephens, M., and Pritchard, J. K. 2009. Inferring weak population structure with the assistance of sample group information. Mol. Ecol. Resour. 9:1322-1332.

Jiang, Y. N., Haudenshield, J. S., and Hartman, G. L. 2012. Characterization of Pythium spp. from soil samples in Illinois. Can. J. Plant Pathol. 34:448-454. 
Kamvar, Z. N., Souza, V., Tabima, J. F., and Grünwald, N. J. 2014. Poppr: an $\mathrm{R}$ package for genetic analysis of populations with clonal, partially clonal, and/or sexual reproduction. PeerJ 2:e281.

Konstantinou, S., Veloukas, T., Leroch, M., Menexes, G., Hahn, M., and Karaoglanidis, G. 2015. Population structure, fungicide resistance profile, and sdhB mutation frequency of Botrytis cinerea from strawberry and greenhouse-grown tomato in Greece. Plant Dis. 99:240-248.

Kumar, S., Stecher, G., and Tamura, K. 2016. MEGA7: Molecular Evolutionary Genetics Analysis version 7.0 for bigger datasets. Mol. Biol. Evol. 33:1870-1874.

Lamour, K. H., and Hausbeck, M. K. 2001. Investigating the spatiotemporal genetic structure of Phytophthora capsici in Michigan. Phytopathology 91:973-980.

Leach, M., Agudelo, P., and Lawton-Rauh, A. 2012. Effect of crop rotations on Rotylenchulus reniformis population structure. Plant Dis. 96:24-29.

Lee, S., Garzon, C. D., and Moorman, G. W. 2010. Genetic structure and distribution of Pythium aphanidermatum populations in Pennsylvania greenhouses based on analysis of AFLP and SSR markers. Mycologia 102: 774-784.

Lee, S., and Moorman, G. W. 2008. Identification and characterization of simple sequence repeat markers for Pythium aphanidermatum, $P$. cryptoirregulare, and $P$. irregulare and the potential use in Pythium population genetics. Curr. Genet. 53:81-93.

Lendenmann, M. H., Croll, D., Palma-Guerrero, J., Stewart, E. L., and McDonald, B. A. 2016. QTL mapping of temperature sensitivity reveals candidate genes for thermal adaptation and growth morphology in the plant pathogenic fungus Zymoseptoria tritici. Heredity 116:384-394.

Lévesque, C. A., and De Cock, W. A. M. 2004. Molecular phylogeny and taxonomy of the genus Pythium. Mycol. Res. 108:1363-1383.

Lin, H., Islam, M. S., Rosa, J. C. C.-L., Civerolo, E. L., and Groves, R. L. 2015. Population structure of Xylella fastidiosa associated with almond leaf scorch disease in the San Joaquin Valley of California. Phytopathology 105:825-832.

Lookabaugh, E. C., Ivors, K. L., and Shew, B. B. 2015. Mefenoxam sensitivity, aggressiveness, and identification of Pythium species causing root rot on floriculture crops in North Carolina. Plant Dis. 99:1550-1558.

Mammella, M. A., Martin, F. N., Cacciola, S. O., Coffey, M. D., Faedda, R., and Schena, L. 2013. Analyses of the population structure in a global collection of Phytophthora nicotianae isolates inferred from mitochondrial and nuclear DNA sequences. Phytopathology 103:610-622.

Martin, F. N. 1992. Pythium. Pages 39-49 in: Methods for Research on Soilborne Phytopathogenic Fungi. L. L. Singleton, J. D. Mihail, and C. M. Rush, eds. American Phytopathological Society, St. Paul, MN.

Martin, F. N. 2000. Phylogenetic relationships among some Pythium species inferred from sequence analysis of the mitochondrially encoded cytochrome oxidase II gene. Mycologia 92:711-727.

Martin, F. N., and Loper, J. E. 1999. Soilborne plant diseases caused by Pythium: Ecology, epidemiology, and prospects for biological control. Crit. Rev. Plant Sci. 18:111-181.

Matsumoto, C., Kageyama, K., Suga, H., and Hyakumachi, M. 2000. Intraspecific DNA polymorphisms of Pythium irregulare. Mycol. Res. 104:1333-1341.

Matthiesen, R. L., Ahmad, A. A., and Robertson, A. E. 2016. Temperature affects aggressiveness and fungicide sensitivity of four Pythium spp. that cause soybean and corn damping off in Iowa. Plant Dis. 100:583-591.

McDonald, B. A., and Mundt, C. C. 2016. How knowledge of pathogen population biology informs management of Septoria tritici blotch. Phytopathology 106: 948-955.

Milgroom, M. G. 2015. Population Biology of Plant Pathogens: Genetics, Ecology, and Evolution. American Phytopathological Society Press, St. Paul, $\mathrm{MN}$

Milgroom, M. G., Jiménez-Gasco, M. D. M., Olivares-García, C., Drott, M. T., and Jiménez-Díaz, R. M. 2014. Recombination between clonal lineages of the asexual fungus Verticillium dahliae detected by genotyping by sequencing. PLoS One 9:e106740.

Milgroom, M. G., Jiménez-Gasco, M. M., Olivares-García, C., and Jiménez-Díaz, R. M. 2016. Clonal expansion and migration of a highly virulent, defoliating lineage of Verticillium dahlie. Phytopathology 106:1038-1046.

Mohd-Assaad, N., McDonald, B. A., and Croll, D. 2016. Multilocus resistance evolution to azole fungicides in fungal plant pathogen populations. Mol. Ecol. 25:6124-6142.

Moorman, G. W., Kang, S., Geiser, D. M., and Kim, S. H. 2002. Identification and characterization of Pythium species associated with greenhouse floral crops in Pennsylvania. Plant Dis. 86:1227-1231.

Olson, H. A., Jeffers, S. N., Ivors, K. L., Steddom, K. C., Williams-Woodward, J. L., Mmbaga, M. T., Benson, D. M., and Hong, C. X. 2013. Diversity and mefenoxam sensitivity of Phytophthora spp. associated with the ornamental horticulture industry in the southeastern United States. Plant Dis. 97:86-92.

Peakall, R., and Smouse, P. E. 2012. GenAlEx 6.5: genetic analysis in Excel. Population genetic software for teaching and research-an update. Bioinformatics 28:2537-2539.

Peever, T. L., Canihos, Y., Olsen, L., Ibañez, A., Liu, Y.-C., and Timmer, L. W. 1999. Population genetic structure and host specificity of Alternaria spp. causing brown spot of Minneola tangelo and rough lemon in Florida. Phytopathology 89:851-860.

Pritchard, J. K., Stephens, M., and Donnelly, P. 2000. Inference of population structure using multilocus genotype data. Genetics 155:945-959.
Radmer, L., Anderson, G., Malvick, D. M., Kurle, J. E., Rendahl, A., and Mallik, A. 2017. Pythium, Phytophthora, and Phytopythium spp. associated with soybean in Minnesota, their relative aggressiveness on soybean and corn, and their sensitivity to seed treatment fungicides. Plant Dis. 101:62-72.

Rizvi, S. S. A., and Yang, X. B. 1996. Fungi associated with soybean seedling disease in Iowa. Plant Dis. 80:57-60.

Rodriguez-Bonilla, L., Cuevas, H. E., Montero-Rojas, M., Bird-Pico, F., LucianoRosario, D., and Siritunga, D. 2014. Assessment of genetic diversity of sweet potato in Puerto Rico. PLoS One 9:e116184.

Santana, Q. C., Coetzee, M. P. A., Steenkamp, E. T., Mlonyeni, O. X., Hammond, G. N. A., Wingfield, M. J., and Wingfield, B. D. 2009. Microsatellite discovery by deep sequencing of enriched genomic libraries. Biotechniques 46:217-223.

Schoebel, C. N., Brodbeck, S., Buehler, D., Cornejo, C., Gajurel, J., Hartikainen, H., Keller, D., Leys, M., Ricanová, S., Segelbacher, A. G., Werth, S., and Csencsics, D. 2013. Lessons learned from microsatellite development for nonmodel organisms using 454 pyrosequencing. J. Evol. Biol. 26:600-611.

Shah, D. A., and Madden, L. V. 2004. Nonparametric analysis of ordinal data in designed factorial experiments. Phytopathology 94:33-43.

Spies, C. F. J., Mazzola, M., Botha, W. J., Langenhoven, S. D., Mostert, L., and Mcleod, A. 2011. Molecular analyses of Pythium irregulare isolates from grapevines in South Africa suggest a single variable species. Fungal Biol. 115:1210-1224.

Stasko, A. K., Wickramasinghe, D., Nauth, B. J., Acharya, B., Ellis, M. L., Taylor, C. G., McHale, L. K., and Dorrance, A. E. 2016. High-density mapping of resistance QTL toward Phytophthora sojae, Pythium irregulare, and Fusarium graminearum in the same soybean population. Crop Sci. 56:2476-2492.

Stefansson, T. S., McDonald, B. A., and Willi, Y. 2013. Local adaptation and evolutionary potential along a temperature gradient in the fungal pathogen Rhynchosporium commune. Evol. Appl. 6:524-534.

Steimel, J., Engelbrecht, C. J. B., and Harrington, T. C. 2004. Development and characterization of microsatellite markers for the fungus Ceratocystis fimbriata. Mol. Ecol. Notes 4:215-218.

Stewart, S., Abeysekara, N., and Robertson, A. E. 2014. Pathotype and genetic shifts in a population of Phytophthora sojae under soybean cultivar rotation. Plant Dis. 98:614-624.

Stewart, S., Robertson, A., Wickramasinghe, D., Draper, M., Michel, A., and Dorrance, A. E. 2016. Population structure among and within Iowa, Missouri, Ohio, and South Dakota populations of Phytophthora sojae. Plant Dis. 100: 367-379.

Suzuki, F., Yamaguchi, J., Koba, A., Nakajima, T., and Arai, M. 2010. Changes in fungicide resistance frequency and population structure of Pyricularia oryzae after discontinuance of MBI-D fungicides. Plant Dis. 94:329-334.

Talas, F., and McDonald, B. A. 2015. Genome-wide analysis of Fusarium graminearum field populations reveals hotspots of recombination. BMC Genomics 16:996.

Thompson, J. D., Higgins, D. G., and Gibson, T. J. 1994. CLUSTAL W: improving the sensitivity of progressive multiple sequence alignment through sequence weighting, position-specific gap penalties and weight matrix choice. Nucleic Acids Res. 22:4673-4680.

Urrea, K., Rupe, J. C., and Rothrock, C. S. 2013. Effect of fungicide seed treatments, cultivars, and soils on soybean stand establishment. Plant Dis. 97: 807-812.

van der Plaats-Niterink, A. J. 1981. Monograph of the Genus Pythium. Studies in Mycology. Centraalbureau voor Schimmelculture, Baarn, Netherlands.

Villa, N. O., Kageyama, K., Asano, T., and Suga, H. 2006. Phylogenetic relationships of Pythium and Phytophthora species based on ITS rDNA, cytochrome oxidase II and b-tubulin gene sequences. Mycologia 98:410-422.

Wang, P. H., and White, J. G. 1997. Molecular characterization of Pythium species based on RFLP analysis of the internal transcribed spacer region of ribosomal DNA. Physiol. Mol. Plant Pathol. 51:129-143.

Waterhouse, G. M. 1967. Key to Pythium Pringsheim. Mycol. Pap. 109:1-15.

Wei, L., Xue, A. G., Cober, E. R., Babcock, C., Zhang, J., Zhang, S., Li, W., Wu, J., and Liu, L. 2010. Pathogenicity of Pythium species causing seed rot and damping-off in soybean under controlled conditions. Phytoprotection 91:3-10.

Weiland, J. E., Garrido, P., Kamvar, Z. N., Marek, S. M., Garz, C. D., and Espíndola, A. S. 2015. Population structure of Pythium irregulare, $P$ ultimum, and $P$. sylvaticum in forest nursery soils of Oregon and Washington. Phytopathology 105:684-694.

Weiland, J. E., Santamaria, L., and Grünwald, N. J. 2014. Sensitivity of Pythium irregulare, P. sylvaticum, and P. ultimum from forest nurseries to mefenoxam and fosetyl-Al, and control of Pythium damping-off. Plant Dis. 98:937-942.

White, J. G., Lyons, N. F., Wakeham, A. J., Mead, A., and Green, J. R. 1994 Serological profiling of the fungal genus Pythium. Plysiological Mol. Plant Pathol. 44:349-361.

White, T. J., Bruns, T., Lee, S., and Taylor, J. 1990. Amplification and direct sequencing of fungal ribosomal RNA genes for phylogenetics. Pages 315-322 in: PCR Protocols: A Guide to Methods and Applications. M. A. Innis, D. H. Gelfand, and J. J. Snisky, eds. Academic Press, San Diego, CA.

Zelaya-Molina, L. X., Ortega, M. A., and Dorrance, A. E. 2011. Easy and efficien protocol for oomycete DNA extraction suitable for population genetic analysis. Biotechnol. Lett. 33:715-720.

Zitnick-Anderson, K. K., and Nelson, B. D. 2015. Identification and pathogenicity of Pythium on soybean in North Dakota. Plant Dis. 99:31-38. 